IZA DP No. 8008

Non-Farm Entrepreneurship in Rural Africa:

Patterns and Determinants

Paula Nagler

Wim Naudé

February 2014

Forschungsinstitut

zur Zukunft der Arbeit

Institute for the Study

of Labor 


\title{
Non-Farm Entrepreneurship in Rural Africa: Patterns and Determinants
}

\author{
Paula Nagler \\ UNU-MERIT/Maastricht Graduate School of Governance \\ Wim Naudé \\ Maastricht School of Management, UNU-MERIT/MGSoG \\ and IZA
}

Discussion Paper No. 8008

February 2014

IZA

P.O. Box 7240

53072 Bonn

Germany

Phone: +49-228-3894-0

Fax: +49-228-3894-180

E-mail: iza@iza.org

\begin{abstract}
Any opinions expressed here are those of the author(s) and not those of IZA. Research published in this series may include views on policy, but the institute itself takes no institutional policy positions. The IZA research network is committed to the IZA Guiding Principles of Research Integrity.

The Institute for the Study of Labor (IZA) in Bonn is a local and virtual international research center and a place of communication between science, politics and business. IZA is an independent nonprofit organization supported by Deutsche Post Foundation. The center is associated with the University of Bonn and offers a stimulating research environment through its international network, workshops and conferences, data service, project support, research visits and doctoral program. IZA engages in (i) original and internationally competitive research in all fields of labor economics, (ii) development of policy concepts, and (iii) dissemination of research results and concepts to the interested public.
\end{abstract}

IZA Discussion Papers often represent preliminary work and are circulated to encourage discussion. Citation of such a paper should account for its provisional character. A revised version may be available directly from the author. 
IZA Discussion Paper No. 8008

February 2014

\section{ABSTRACT \\ Non-Farm Entrepreneurship in Rural Africa: Patterns and Determinants}

We are the first to provide a comparative empirical analysis of non-farm entrepreneurship in rural Africa, using the World Bank's unique LSMSISA dataset. This dataset covers six countries over the period 2005 to 2012. We find that rural enterprises tend to be small, informal household enterprises that provide predominantly goods and services to the local economy, and operate intermittently due to seasonality in farming. We furthermore establish that the likelihood of operating an off-farm enterprise depends on individual capabilities, household characteristics and institutional factors. While the results of some variables show consistency across the sample, we also find much heterogeneity, suggesting that rural entrepreneurship is also a response to country-level circumstances and policies. Although more than 50 years have passed since rural development was identified as a priority for African countries, rural entrepreneurship continues to fulfill mainly a risk-diversifying role. This may suggest that policies to foster effective rural-urban migration and wage employment in rural areas, have largely failed in Africa.

\section{NON-TECHNICAL SUMMARY}

This paper provides an empirical description of the patterns and determinants of non-farm entrepreneurship in rural Africa. It uses the World Bank's LSMS-ISA dataset on six countries: Ethiopia, Niger, Nigeria, Malawi, Tanzania and Uganda. It finds that non-farm entrepreneurship predominantly creates informal jobs and mostly for family members; that these jobs tend to be transient and influenced by seasonality in agriculture; and that there is substantial heterogeneity across countries in the determinants of rural non-farm entrepreneurship.

JEL Classification: Q12, O13, O55, M13, J43

Keywords: entrepreneurship, rural development, Sub-Saharan Africa, informal sector, labour markets, small business, SMEs

Corresponding author:

Wim Naudé

Maastricht School of Management

PO Box 1203

6201 BE Maastricht

The Netherlands

E-mail: naude@msm.nl 


\section{Introduction}

Around a decade ago, Wiggens (2000) lamented the fact that "little is known" about Africa's rural non-farm economy, beyond an "embryonic set of ideas". Studies based on consistent and cross-country comparable householdlevel data focusing on self-employment or entrepreneurship in the African rural non-farm economy have been limited, although we now know that this sector contributes with a relatively large and increasing share to household income in rural Africa (Davis et al., 2007; Reardon et al., 2006; Rijkers and Costa, 2012; Start, 2001). Since then the potential importance of the rural non-farm sector has become firmly established, and the embryonic set of ideas mentioned by Wiggens elaborated in more detail by scholars. The why, when and how of rural non-farm enterprises remain however relatively unexplored from a comparative perspective. Most of the small (but growing) scholarly literature makes use of one-period, single-country, and often rather limited survey data. Indeed, most empirical studies on entrepreneurship in Africa have focused on self-employment in urban areas. The neglect of a more solid empirical knowledge of rural entrepreneurship in Africa may be a contributing factor in the limited success of rural development policies, and of the fact that rural entrepreneurship does not feature in most poverty alleviation or entrepreneurship promotion strategies in Africa (Fox and Sohnesen, 2013).

The contribution of this paper lies in filling this gap by providing, on the one hand, comparative descriptive statistics on the patterns of rural nonfarm enterprise characteristics; on the other hand, empirical estimates using probit regressions to identify individual, household and location variables that can explain the likelihood of rural households operating a non-farm enterprise. Our analysis is based on the recently available Living Standards Measurement Study - Integrated Surveys in Agriculture (LSMS-ISA) data set that covers six countries over the period 2005 to 2012: Ethiopia, Malawi, Niger, Nigeria, Tanzania and Uganda. ${ }^{1}$

We find that rural non-farm enterprises are largely small and informal. They provide predominantly goods and services to the local economy, and are operated in most instances from within the household dwelling or the immediate surroundings. They also reflect seasonality in farming, as only a share of en-

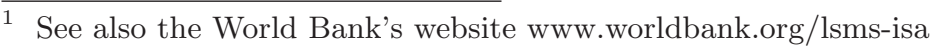


terprises are operated continuously throughout the year. The likelihood of operating an enterprise depends on individual capabilities, household characteristics and institutional factors. While the results of some variables show consistency across the sample, we also find much heterogeneity, suggesting that rural entrepreneurship is also a response to country-level circumstances and policies. Although helping households to manage risks, overall rural entrepreneurship does not seem to contribute significantly to employment creation, income growth and structural development in Africa.

The paper is organized as follows: in section 2 we discuss the relevant literature and link it to our own empirical analysis. In section 3 we describe the database and the method used. In section 4 we present and discuss our empirical findings on the patterns and determinants of rural non-farm entrepreneurship. The final section concludes.

\section{Relevant Literature}

\subsection{Key Concepts}

At the outset we clarify what we mean by rural non-farm entrepreneurship: self-employment in the rural non-farm economy. ${ }^{2}$ This is consistent with definitions and measures of entrepreneurship as the creation of a business enterprise and working for one's own account (Naudé, 2011). With the rural non-farm economy we understand a residual sector wherein all non-farm activities in rural areas are captured, including agribusiness, services, trade and retail, tourism, rural industrialization, construction, and mining. Although described as non-farm, many of these activities are linked to agriculture and can actually take place on a farm (e.g. food processing, veterinary services) (Rijkers and Costa, 2012). Barrett et al. (2001) contain a more detailed discussion of the concepts of the rural economy in general, including agriculture and the non-farm economy, and Roepstorff and Wiggens (2011) on the concept and measurement of agribusiness.

2 There are many entrepreneurs in farming. In this paper however our focus is not on the farmer-as-entrepreneur, but on the self-employment/entrepreneurship activities of individual household members in rural areas. 


\subsection{Importance of the Rural Non-Farm Economy}

As we mentioned in the introduction, the why, when and how of rural nonfarm enterprises in Africa remain relatively unexplored from a comparative perspective. Until fairly recently a lack of comparable cross-country data limited an empirical comparative analysis of the rural non-farm economy. The Rural Income Generating Activities (RIGA) database is a first effort to overcome this limitation. It has been constructed by the FAO and World Bank from the LSMS for about 15 countries. ${ }^{3}$ As far as the patterns of the rural non-farm economy are concerned, an analysis of the RIGA data base by Davis et al. (2007) find that rural non-farm activities contributed more than 50 percent to rural household income in 11 out of 15 countries, with an average across countries of 58 percent. They also find that the share of non-farm income is however less important in Africa compared to other regions.

This lack of empirical knowledge about the patterns and determinants of rural entrepreneurship in Africa may be a contributing factor in the limited success of rural development policies and structural change in Africa, and of the fact that rural entrepreneurship does not feature in most poverty alleviation or entrepreneurship promotion strategies (Fox and Sohnesen, 2013). Although data limitations undoubtedly are to blame, the neglect of rural entrepreneurship in Africa can also be explained by the (earlier) thinking on rural development in Africa, wherein the rural economy was expected to become less important as a contributor to rural household income over time (Lanjouw and Lanjouw, 2001). Urbanization and industrialization have been consequently a focus of development policies for much of the period since the 1960s, with the agricultural sector often (implicitly) repressed and regulated (Havnevik et al., 2003). Most empirical studies on entrepreneurship in Africa hence focus on urban areas.

That the rural non-farm entrepreneurship could potentially be important for development was only recognized from the late 1990s onwards, when it became clear that, contrary to expectations, the contribution of the sector to rural household income did not decline over time, but in fact increased (Davis et al., 2007; Reardon et al., 2006). Today, the literature suggests that

3 The RIGA data set covers around 90,000 observations across Albania, Bangladesh, Bulgaria, Ecuador, Ghana, Guatemala, Indonesia, Madagascar, Malawi, Nepal, Nicaragua, Nigeria, Pakistan, Panama and Vietnam. 
between 40 and 50 percent of household income in rural Africa originates from rural non-farm entrepreneurship (Davis et al., 2007; Reardon et al., 2006; Rijkers and Costa, 2012; Start, 2001; Lanjouw and Lanjouw, 2001). For many of the countries under closer scrutiny in this paper, Reardon et al. (2006) report findings on the share of rural household income emanating from the non-farm economy. For instance in Ethiopia the share was 20 percent in 1999, in Malawi 64 percent in 2004, and for Uganda and Tanzania 54 and 46 percent in 2000 , respectively.

Most of the empirical work on rural non-farm entrepreneurship confirms that it is a very heterogeneous sector (e.g. Davis and Bezemer, 2004; Barrett et al., 2001). Davis et al. (2007) find that most non-farm entrepreneurial activities consist of very small and informal businesses in the commercial, trade and services sectors. The persistence of the smallness of firms in Africa is noteworthy, as Haggblade et al. (1989) find that 95 percent of the rural non-farm enterprises employ less than five workers. In-depth studies on the patterns and determinants of growth, and their start-up and failure rates have however been hampered by a lack of panel data. The few studies that exist have shed some light on the conditions that drive growth and failure in this sector over time.

Outside of Africa, Janvry and Sadoulet (2001) find that in Mexico the nonfarm economy contributes on average with 55 percent to rural household income. Escobal (2001) reports a figure of 51 percent for Peru. Lanjouw and Lanjouw (2001) report figures of 39 percent for Brazil, 41 percent for Chile, 50 percent for Colombia and 59 percent for Costa Rica. Shi et al. (2007) report 46 percent for China.

\subsection{Determinants}

In order to understand what determines the share of non-farm income in Africa and why it is lower than elsewhere, we need to identify the determinants of (and hence obstacles to) rural non-farm entrepreneurship. Relatively few studies have dealt with this, and many of those that do, have been hampered by a lack of comparative and longitudinal data. Nevertheless extant studies have made useful contributions, particularly in trying to disentangle the determinants of the decision of rural households to start a non-farm enterprise into push and pull factors, with household capabilities 
and the institutional environment mediating (Reardon et al., 2006).

One of the most important push factors is the high degree of risk in African agriculture (Rijkers and Söderbom, 2013). Risk-averse farm households are keen to diversify their income ex-ante in anticipation that a crop may fail; or ex-post in the aftermath of a shock (Ackah, 2013). Rural entrepreneurship as such is a form of self-insurance in the face of limited insurance markets. Longer-term structural push factors include surplus labor on farms, as growing families put pressure on fixed parcels of farmland over time (Babatunde and Qaim, 2010; Reardon, 1997; Reardon et al., 2006). Push factors also include seasonality: household members may be pushed off-farm in the offseason. As such rural non-farm activities are secondary activities (Lanjouw and Lanjouw, 2001), and we expect to see a share of non-farm enterprises that do not operate continuously throughout the year.

Whether households start non-farm enterprises may also be due to their desire to utilize business opportunities, so called pull factors into entrepreneurship. In this regard household capabilities and assets, as well as individual characteristics have been found to be crucial (Barrett et al., 2001). Household capabilities and assets typically include gender, age (also a proxy for experience), education, marital status (Abdulai and Delgado, 1999), as well as financial assets (Ackah, 2013; Bhaumik et al., 2011), and the size of the household itself. ${ }^{4}$ Women, at least in Africa, have been found to be more likely to engage in the non-farm economy (Ackah, 2013; Canagarajah et al., 2001; Rijkers and Costa, 2012) or to migrate (Shi et al., 2007) compared to men. Schooling seems to be relatively more important for finding non-farm wage employment than for starting a new business (Bayene, 2008; Davis et al., 2007; Elbers and Lanjouw, 2001; Reardon et al., 2006).

Both push and pull factors are influenced by the features of the local and regional economies where households are based (mostly exogenous for the household). For instance the agro-climatic environment determines the extent to which farming is productive and/or risky (Reardon, 1997). There is evidence that rural entrepreneurship fares better under favorable agroclimatic conditions (e.g. better rainfall) that are good for agricultural productivity and where other natural resources, e.g. in mines and tourist attractions, can be found (Reardon et al., 2006). The location of the household also

4 The presence of children in a household may limit the choices of individual household members, particularly women, within the non-farm economy, resulting e.g. in activities attached to the household residence (Havnevik et al., 2003). 
determines the distance from urban areas, ports and markets. Fafchamps and Shilpi (2003) find that the share of non-farm wage employment declines the further a household lives away from a urban center, and that there is a U-shaped relationship between distance from a urban center and the share of income from self-employment. This finding suggests some kind of protection effect of deep rural isolation on non-farm enterprises. Also, the closer a household is located to an urban center, the more likely an individual household members migrates to this urban area (Reardon, 1997). Generally distance, but also other determinants of market access such as the quality of roads and utilities, can be important determinants of development in both the farm and non-farm economy of Africa, and of the linkages between the two (Wiggens, 2000; Roepstorff and Wiggens, 2011).

\subsection{Summary}

Summarizing this section, we discussed the relevant literature on the patterns and determinants of rural non-farm entrepreneurship in Africa, and showed that this literature has established that, contrary to earlier expectations, the share of rural household income originating from the non-farm economy did not decline over time, but in fact increased. As this share is around 40 per cent in rural Africa, smaller than elsewhere in the world, it is important to identify the determinants of rural household participation in the non-farm economy.

The existing literature has usefully made a distinction between push and pull factors, and has found based mainly on individual country studies, push factors such as shocks/risks, and surplus family labor to be significant, whereas pull factors such a individual and household level capabilities and assets, as well as institutional and regional features such as access to credit and infrastructure, to be significant. In the remainder of the paper we explore the LSMS-ISA dataset to investigate the patterns of non-farm entrepreneurship in rural Africa, and we use a probit regression analysis to identify the determinants of rural non-farm entrepreneurship. Based on the literature, we classify the determinants into shocks and risks, individual and household level determinants, local and regional features and access to credit. Before we report these new empirical findings in section 4, we first explain the dataset and our estimation methods. 


\section{Data and Methodology}

\subsection{The Database}

The LSMS-ISA database covers six countries in Sub-Saharan Africa: Ethiopia, Malawi, Niger, Nigeria, Tanzania and Uganda. ${ }^{5}$ In all countries where LSMS-ISA surveys have taken place, the plan is to conduct surveys every three years to obtain longitudinal data. At present a cross-sectional data base is available for all six countries, and panel data for Tanzania and Uganda.

The questionnaire used has three sections: a community section, an agricultural section and a household section. The community section records access to public services and infrastructure, social networks, governance, and retail prices. The agricultural section records crop production, storage and sales, land holdings, farming practices, input use and technology adaption, access to and use of services, infrastructure and natural resources, livestock, and fishery. And the household questionnaire records household demographics, education, health and nutrition, food consumption and expenditure, nonfood expenditure, employment, non-farm self-employment and other sources of income, dwelling conditions, durable assets, migration, and participation in projects and programs. The survey data has also been geo-referenced, which allows us to include the impact of geographically determined variables such as rainfall, and distances from major roads and urban centers into our regression analysis.

Although the data set is new, unique and facilitates the comparability between countries (a feature that has so far been lacking in the available data), shortcomings remain that we need to acknowledge. For instance, while all six countries include a section with a set of questions covering the area of nonfarm enterprises, the availability of certain questions differs between countries and not all aspects are included in all country questionnaires. Questions that are available in all, or at least the majority of countries, often contain different answer possibilities of survey participants, also reflecting the specific country context.

In the following section we use the LSMS-ISA data in two ways: first we

$\overline{5}$ Data will also be collected for Mali in time. 
explore the database to identify the salient patterns of rural non-farm entrepreneurship (we describe this in section 4.1). Second, we run a number of probit regressions to identify determinants of or factors associated with the decision of households to participate in rural non-farm entrepreneurship (we report the results in section 4.2). Before proceeding, we use the next subsection to explain our estimation methods.

\subsection{Estimation Method}

We use probit regressions to identify the factors that determine or are associated with the probability that a rural household operates a non-farm enterprise. Formally we estimate

$$
\operatorname{Pr}\left(Y_{i} \mid \mathbf{X}_{i}, \mathbf{W}_{i}, \mathbf{Z}_{i}\right)=\Phi\left(\beta \mathbf{X}_{i}+\delta \mathbf{W}_{i}+\gamma \mathbf{Z}_{i}\right)
$$

where the dependent variable is a binary variable equal to one if a household operates a non-farm enterprise, and zero if not. $\mathbf{X}_{i}$ represents a vector of individual characteristics including a constant, and comprises the variables gender, age, education (ability to read and write) and marital status of the household head. $\mathbf{W}_{i}$ represents a vector of household characteristics including household size, the share of adults (household members age 15 or older), the number of rooms in the dwelling as an approximation to household wealth, and a binary variable if a household member has taken out credit over the past 12 months, indicating the possibility of accessing financial support. Furthermore a binary variable if the household experienced food shortage or a shock over the past 12 months (idiosyncratic shocks, geographic shocks, institutional shocks and other shocks). Finally $\mathbf{Z}_{i}$ represents a set of location variables, also named geo variables, including the household distance to the next major road, the distance to the next population center, and annual precipitation. These variables are based on our literature review. 


\section{Empirical Analysis}

In section 4.1 we first explore the data and provide a set of tables and figures with relevant patterns and characteristics of rural non-farm entrepreneurship, focusing on the extent and nature of entrepreneurial activities. In section 4.2 we then present the regression results on the determinants of participation.

\subsection{Patterns of Rural Non-Farm Entrepreneurship}

One of the established facts in the literature we highlighted in section 2 is that non-farm entrepreneurship contributes a significant share to the income of rural households in Africa. The data from the LSMS-ISA is consistent with this fact: non-farm entrepreneurship activities are widely prevalent in the six African countries surveyed. As shown in Table 1 almost 42 percent out of the 24,551 rural households surveyed reported operating a non-farm enterprise (NFE in the table). Overall, our sample comprises 11,064 single non-farm enterprises in 8,137 rural households, resulting in an average of 1.36 enterprises per household (evidence of portfolio entrepreneurship). The country shares however vary widely, from as little as 17 percent in rural Malawi, to almost 62 percent in rural Niger.

Table 1: Prevalence of rural non-farm enterprises

\begin{tabular}{lrrrrrr}
\hline Country & $\begin{array}{r}\text { Nr of HH } \\
\text { surveyed }\end{array}$ & $\begin{array}{r}\text { HH with } \\
\text { NFE }\end{array}$ & in \% & $\begin{array}{r}\text { in \% } \\
\text { weighted }\end{array}$ & $\begin{array}{r}\text { Nr of } \\
\text { NFEs }\end{array}$ & $\begin{array}{r}\text { Avg Nr of } \\
\text { NFE/HH }\end{array}$ \\
\hline Ethiopia & 3,969 & 1,212 & 30.54 & 23.23 & 1,482 & 1.22 \\
Malawi & 10,038 & 1,755 & 17.48 & 16.88 & 1,872 & 1.07 \\
Niger & 2,430 & 1,427 & 58.72 & 61.73 & 2,188 & 1.53 \\
Nigeria & 3,380 & 1,707 & 50.50 & 52.62 & 2,688 & 1.57 \\
Tanzania & 2,629 & 1,083 & 41.19 & 39.10 & 1,363 & 1.26 \\
Uganda & 2,105 & 953 & 45.27 & 42.24 & 1,471 & 1.54 \\
\hline Total & 24,551 & 8,137 & 33.14 & 41.68 & 11,064 & 1.36 \\
\hline
\end{tabular}

Source: Authors' calculations based on LSMS-ISA data.

Notes: weighted country shares are calculated using survey weights, total share includes population weight.

As for the share of household income deriving from these enterprises, we only 
have sufficient responses from Ethiopia. This indicates hat approximately 27 percent of households engaged in non-farm entrepreneurship derive 50 percent or more of their income from these activities, and approximately 5 percent of households all income. This is consistent with previous estimates.

Using the Rural Income Generating Activities (RIGA) data set of the FAO, we derive shares of household income by household activity for four countries: Malawi 2010/11, Niger 2011, Tanzania 2008/09, and Uganda 2010/11. Figure 1 shows the high importance of agricultural income and agricultural wages in rural areas, and the share of self-employment: while it contributes with less than 9 percent to total household income in Malawi, it represents as much as 36 percent in Niger, 16 in Tanzania and almost 21 percent in Uganda. Comparing to urban areas (not included in Figure 1), the share of agricultural income is decisively more important in rural areas, and income deriving from self-employment smaller. In urban areas self-employment contributes with 22 percent in Malawi, 48 percent in Niger, 43 percent in Tanzania and 33 percent in Uganda to household income (percentages rounded).

Figure 1: Contribution of activity to total household income (in \%)

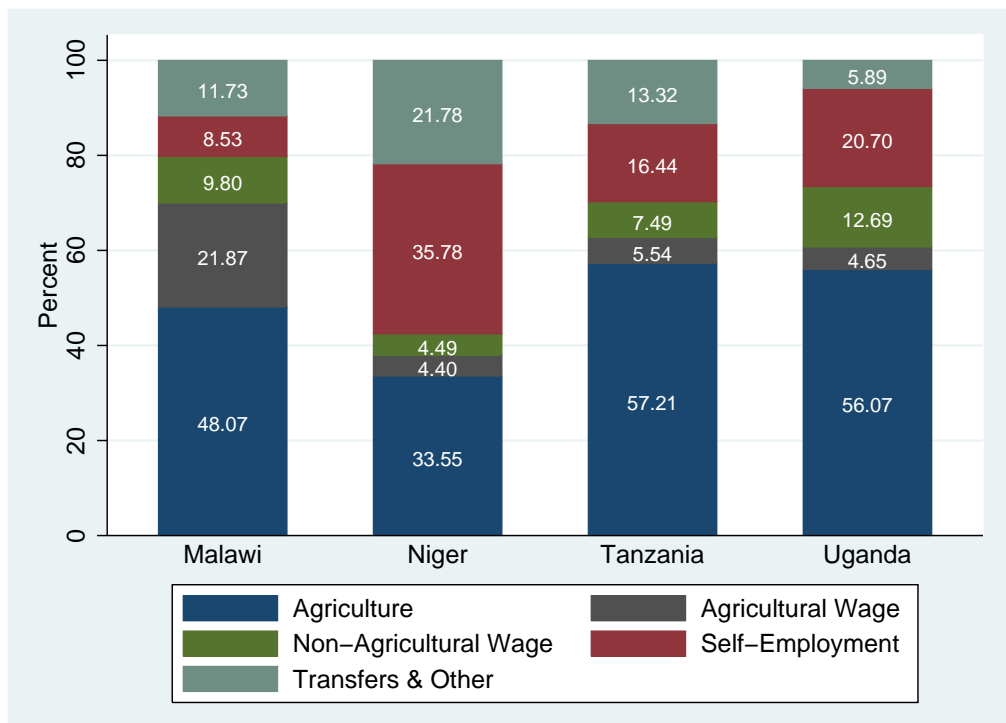

Source: Authors' calculations based on RIGA data (weighted shares).

Note: Rural areas only.

The data furthermore casts doubt on the jobccreation potential of rural entrepreneurship. The vast majority of non-farm enterprises surveyed are small 
household enterprises: over 80 percent of the enterprise owners reported that they do not employ any non-household worker, and less than three percent employ five or more non-household members. This suggests that non-farm enterprises are not significant drivers of wage employment in rural Africa. It seems likely that non-farm enterprises fulfill a survival or risk-diversification strategy for rural households. This is also consistent with the existing literature that we discussed in section 2. In addition we can mention that Davis et al. (2007) find, using the RIGA data set, that most non-farm entrepreneurial activities consist of very small and informal businesses in the commercial, trade and services sectors, and Haggblade et al. (1989), using cross-country data, that 95 percent of the rural non-farm enterprises employ five or less workers.

The assumption that rural non-farm entrepreneurship mainly fulfills a survivalist function is further strengthened by the fact that between 91 and almost 100 percent are operating informally. In Ethiopia, the country with the highest rate of formality, only 8.95 percent of rural enterprises have a license to operate, while in Niger only a very tiny 0.39 percent are registered with the government. ${ }^{6}$ Our findings confirm that non-farm entrepreneurship is prominent in rural Africa, contributing to household activities and income, but with lower importance compared to urban areas. It furthermore does not contribute significantly to creation of wage employment in rural areas.

The data further shows that almost half of the non-farm business is operated from inside the household's residence or in the immediate surroundings (see Figure 2). Rural non-farm enterprise activity is thus household-focused, as the predominant employment of household members also suggests. Most of the enterprise activity that is not in the surroundings of the household residence, is either located in a traditional market place or performed mobile. Less than 5 percent of rural non-farm enterprise activities are located in a commercial district or shop premises, emphasizing the largely informal nature of non-farm enterprise activities in rural Africa.

6 The definition of informal differs slightly between the various questionnaires. For instance in Ethiopia formal firms are those with a license to operate, in Malawi enterprises registered with the Malawi Revenue Authority, in Niger enterprises with a fiscal identification number, in Nigeria whether the enterprise is registered with the government, and in Uganda whether the enterprise is registered for income tax and/or VAT. There were no questions in the Tanzania survey that recorded the formality of rural non-farm enterprises of households surveyed. 
Figure 2: Place of business operation

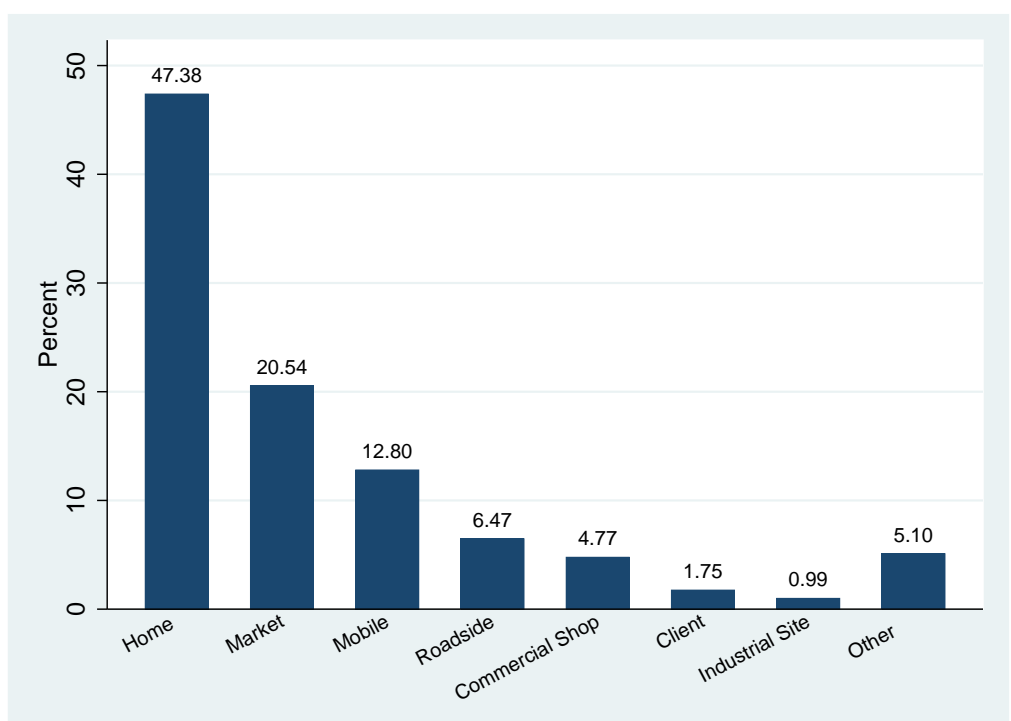

Source: Authors' calculations based on LSMS-ISA data (weighted shares and population weights).

Corresponding to these places of enterprise operation, most households indicate that their enterprises are providing consumer goods or services, or are engaged in trading. Between 20-30 percent of households indicate that their non-farm enterprises are engaged in processing of agricultural products. This is a surprising finding raising the question why agri-business is not more prevalent. This question is reinforced when one considers the responses of rural household enterprises as to the nature of their business clients. They reported that local final consumers is the most important customer base, accounting for 77 percent of sales. Most of the remainder of their sales are to markets, small businesses and traders in the local environment. Rural non-farm enterprises thus sell very little to governments, NGOs or manufacturing firms, the main actors in most rural development support programs. Hence these programs seem overall largely irrelevant for most rural non-farm enterprises in Africa.

Although little research exists on the subject, it may be reasonable to suppose that rural entrepreneurship is affected by seasonality. For instance in section 2 we discussed that seasonal variations in agriculture can be a push factor for households to start and operate a non-farm enterprises during 
the off-season. The impact of seasonality will therefore be reflected in the number of months per year a non-farm enterprise is in operation. Seasonal impact may thus lead households to close their enterprises temporarily, for instance when household members are required to work in agriculture. The LSMS-ISA surveys capture the number of months per year a non-farm enterprise was operating in the year preceding the survey. Figure 3 shows a significant proportion of the rural enterprises operating less than six months per year. Only between 42 and 64 percent of all enterprises operate during the whole year, with the highest percentage found in Nigeria.

Figure 3: Months in operation

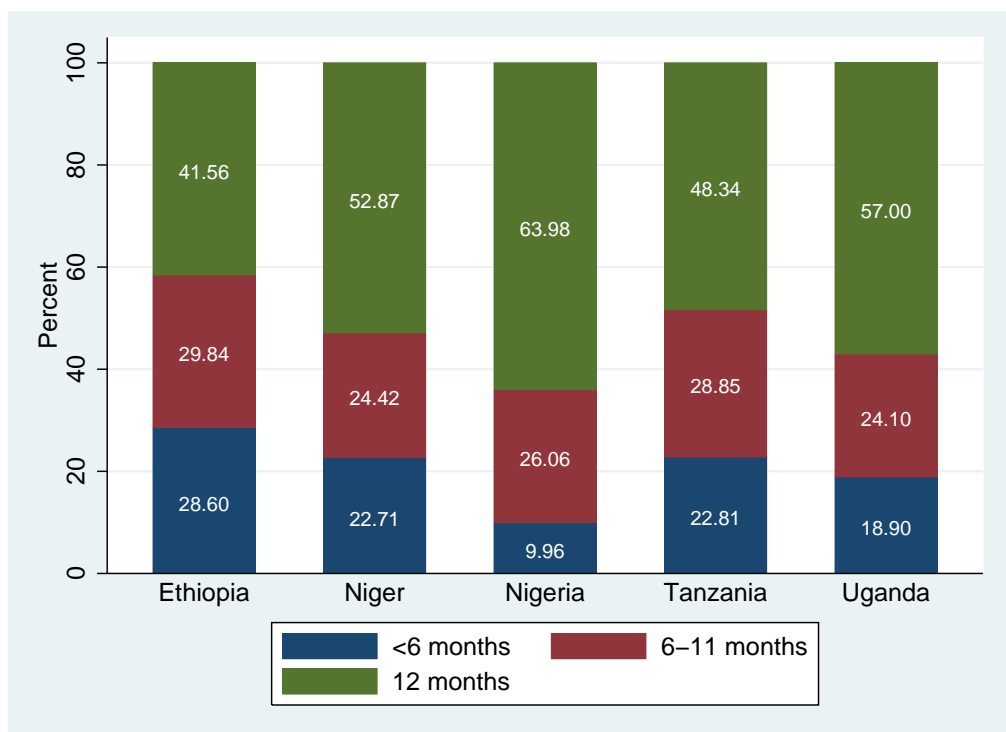

Source: Authors' calculations based on LSMS-ISA data (weighted shares).

Notes: Malawi not reported due to lack of data. Enterprises that are less than one year in operation are exluded.

From the survey we also calculated comparable shares for non-farm enterprises operating in urban areas. As expected, we find that a higher percentage of urban enterprises were in operation throughout the year. As Table 2 indicates, there are proportionately less rural enterprises that operate for 12 months during a year, as compared to urban enterprises. This suggests that seasonality does have a potentially important influence on the dynamics of rural entrepreneurship in Africa.

Summarizing this section we find that, although rural non-farm entrepreneur- 
Table 2: Months of business operation - rural vs. urban (in \%)

\begin{tabular}{|l|cc|cc|cc|cc|}
\hline \multicolumn{4}{c}{ Niger } & \multicolumn{2}{c}{ Nigeria } & \multicolumn{2}{c|}{ Tanzania } & \multicolumn{2}{c|}{ Uganda } \\
\hline & rural & urban & rural & urban & rural & urban & rural & urban \\
$<6$ & 23 & 9 & 10 & 7 & 23 & 12 & 19 & 7 \\
$6-11$ & 24 & 16 & 26 & 24 & 29 & 25 & 24 & 16 \\
12 & 53 & 75 & 64 & 69 & 48 & 63 & 57 & 77 \\
\hline
\end{tabular}

Source: Authors' calculations based on LSMS-ISA data (weighted shares).

ship is prevalent and contributes with a non-negligible share to household income in Africa, it does not appear to be contributing much to the creation of wage employment, nor to structural change or agricultural value-added. It consists primarily of small, informal household enterprises operated by household members. The business is generally operated from within or close to the household residence, or sells products and offers services in traditional markets, targeting local consumers. Seasonality has an impact, especially when comparing with urban enterprises, as a decisive share of the businesses does not operate throughout the year, indicating that labor might be allocated to agricultural work during the planting and harvesting months. Generally the descriptive statistics in this section is consistent with the previous literature.

\subsection{Determinants of Rural Non-Farm Entrepreneurship}

In section 2 we discuss the determinants of rural entrepreneurship as identified in the literature. In this section we set out the results of a probit regression analysis. In the first part we conduct the regressions using the aggregated sample and present also a cross-country analysis to identify sample heterogeneity, in the second part we screen a set of country-specific variables.

\subsubsection{Aggregated Analysis}

First we run a set of probit regressions using the aggregated sample. We include dummies for the different countries, with Ethiopia as the reference category, to have a first overview of variables that are significant in the African context. The results are contained in Table 3. Second, we run 
separate probit regressions for the six different countries of our sample to identify the heterogeneity between countries. The results are contained in Table 4 for rural households, and in Appendix B for all households and urban households.

Table 3 returns the coefficients and average marginal effects of the aggregated data. The first and second column show the results of all households of the sample, the third and fourth column for rural households, and the fifth and sixth column for urban households. It shows that rural households in Africa are on average almost 16 percentage points less likely compared to urban households to operate a non-farm enterprise. Cities are indeed more likely places to find enterprises in Africa, as it is across the world. In the table we also find significant country-level heterogeneity: the probability of a household being involved in running a enterprise is almost 8 percentage points lower in Malawi than in Ethiopia, but 31 percentage points higher in Niger than in Ethiopia. According to Table 3 individual and household level characteristics are important determinants of entrepreneurship overall, as reflected in the statistically significant coefficients on age, marital status, educational attainment ("read \& write") and household size. The signs and magnitudes of some of these coefficients are interesting. For instance educational attainment ("read \& write") is significant in both rural and urban areas, but with a positive effect in rural, and a negative effect in urban areas. This reflects that educated individuals can find wage employment more easily in urban areas, but that this option for educated individuals is largely lacking in the rural non-farm economy in African countries.

As elsewhere in the literature push factors in the form of shocks and risks significantly affect rural entrepreneurship; the effects are however of a complex nature. Households that have experienced food shortages are 2.3 percentage points more likely to operate a non-farm enterprise. "Other shocks" are significant for the aggregate sample and for rural households (and have a positive impact suggesting a fallback option), geographical shocks are only significant for the aggregate sample (at 10 percent) and have a negative coefficient, suggesting a lower likelihood of operating a non-farm enterprise. Also, distance to a road is a significant determinant for non-farm entrepreneurship in rural areas with a negative impact (at 10 percent), but not significant for urban households. This result suggests that market access can constrain rural entrepreneurship and that investment in transport and transport infrastructure may encourage rural entrepreneurship. 
Table 3: Probit regressions - complete sample (coefficients and average marginal effects)

\begin{tabular}{|c|c|c|c|c|c|c|}
\hline $\begin{array}{l}\text { Dependent } \\
\text { NFE }\end{array}$ & $\begin{array}{c}(1) \\
\text { All Countries } \\
\end{array}$ & $\begin{array}{c}(2) \\
\mathrm{AME} \\
\end{array}$ & $\begin{array}{c}(3) \\
\text { Rural } \\
\end{array}$ & $\begin{array}{c}(4) \\
\mathrm{AME} \\
\end{array}$ & $\begin{array}{c}(5) \\
\text { Urban } \\
\end{array}$ & $\begin{array}{c}(6) \\
\text { AME }\end{array}$ \\
\hline Rural & $\begin{array}{c}-0.430^{* * *} \\
(0.06)\end{array}$ & $\begin{array}{c}-0.156^{* * *} \\
(0.02)\end{array}$ & & & & \\
\hline Female & $\begin{array}{l}0.121 \\
(0.08)\end{array}$ & $\begin{array}{c}0.040^{* *} \\
(0.02)\end{array}$ & $\begin{array}{l}0.081 \\
(0.05)\end{array}$ & $\begin{array}{l}0.028 \\
(0.02)\end{array}$ & $\begin{array}{l}0.111 \\
(0.10)\end{array}$ & $\begin{array}{l}0.037 \\
(0.03)\end{array}$ \\
\hline Rural x Female & $\begin{array}{c}-0.009 \\
(0.09)\end{array}$ & & & & & \\
\hline Age & $\begin{array}{c}0.014^{* * *} \\
(0.01)\end{array}$ & $\begin{array}{c}-0.001^{* * *} \\
(0.00)\end{array}$ & $\begin{array}{l}0.010 \\
(0.01)\end{array}$ & $\begin{array}{c}-0.002^{* * *} \\
(0.00)\end{array}$ & $\begin{array}{c}0.023^{* *} \\
(0.01)\end{array}$ & $\begin{array}{l}-0.001 \\
(0.00)\end{array}$ \\
\hline Age2 & $\begin{array}{c}-0.000^{* * *} \\
(0.00)\end{array}$ & & $\begin{array}{c}-0.000^{* * *} \\
(0.00)\end{array}$ & & $\begin{array}{c}-0.000^{* * *} \\
(0.00)\end{array}$ & \\
\hline Married & $\begin{array}{c}0.100^{* *} \\
(0.05)\end{array}$ & $\begin{array}{c}0.035^{* *} \\
(0.02)\end{array}$ & $\begin{array}{l}0.035 \\
(0.05)\end{array}$ & $\begin{array}{l}0.012 \\
(0.02)\end{array}$ & $\begin{array}{c}0.164^{*} \\
(0.09)\end{array}$ & $\begin{array}{c}0.056^{*} \\
(0.03)\end{array}$ \\
\hline Read \& Write & $\begin{array}{c}0.157^{* * * *} \\
(0.03)\end{array}$ & $\begin{array}{c}0.055^{* * *} \\
(0.01)\end{array}$ & $\begin{array}{c}0.217^{* * *} \\
(0.04)\end{array}$ & $\begin{array}{c}0.077^{* * *} \\
(0.01)\end{array}$ & $\begin{array}{c}-0.157^{* *} \\
(0.08)\end{array}$ & $\begin{array}{c}-0.052^{* *} \\
(0.02)\end{array}$ \\
\hline HH Size & $\begin{array}{c}0.082^{* * *} \\
(0.01)\end{array}$ & $\begin{array}{c}0.021^{* * *} \\
(0.00)\end{array}$ & $\begin{array}{c}0.069^{* * *} \\
(0.01)\end{array}$ & $\begin{array}{c}0.020^{* * *} \\
(0.00)\end{array}$ & $\begin{array}{c}0.183^{* * *} \\
(0.03)\end{array}$ & $\begin{array}{c}0.032^{* * *} \\
(0.01)\end{array}$ \\
\hline HH Size2 & $\begin{array}{c}-0.002^{* * *} \\
(0.00)\end{array}$ & & $\begin{array}{c}-0.001^{*} \\
(0.00)\end{array}$ & & $\begin{array}{c}-0.010^{* * *} \\
(0.00)\end{array}$ & \\
\hline Share of Adults & $\begin{array}{r}-0.026 \\
(0.08)\end{array}$ & $\begin{array}{l}-0.009 \\
(0.03)\end{array}$ & $\begin{array}{l}0.109 \\
(0.08)\end{array}$ & $\begin{array}{l}0.038 \\
(0.03)\end{array}$ & $\begin{array}{c}-0.186 \\
(0.20)\end{array}$ & $\begin{array}{c}-0.063 \\
(0.07)\end{array}$ \\
\hline Food Shortage & $\begin{array}{l}0.065^{*} \\
(0.04)\end{array}$ & $\begin{array}{l}0.023^{*} \\
(0.01)\end{array}$ & $\begin{array}{l}0.049 \\
(0.04)\end{array}$ & $\begin{array}{l}0.017 \\
(0.01)\end{array}$ & $\begin{array}{l}0.086 \\
(0.08)\end{array}$ & $\begin{array}{l}0.029 \\
(0.03)\end{array}$ \\
\hline Shock (idiosyn.) & $\begin{array}{l}-0.002 \\
(0.03)\end{array}$ & $\begin{array}{l}-0.001 \\
(0.01)\end{array}$ & $\begin{array}{l}0.009 \\
(0.04)\end{array}$ & $\begin{array}{l}0.003 \\
(0.01)\end{array}$ & $\begin{array}{l}-0.029 \\
(0.07)\end{array}$ & $\begin{array}{l}-0.010 \\
(0.02)\end{array}$ \\
\hline Shock (geogr.) & $\begin{array}{c}-0.067^{*} \\
(0.04)\end{array}$ & $\begin{array}{c}-0.024^{*} \\
(0.01)\end{array}$ & $\begin{array}{c}-0.055 \\
(0.04)\end{array}$ & $\begin{array}{l}-0.019 \\
(0.02)\end{array}$ & $\begin{array}{r}-0.131 \\
(0.10)\end{array}$ & $\begin{array}{l}-0.045 \\
(0.04)\end{array}$ \\
\hline Shock (institut.) & $\begin{array}{l}0.005 \\
(0.04)\end{array}$ & $\begin{array}{l}0.002 \\
(0.01)\end{array}$ & $\begin{array}{l}0.005 \\
(0.05)\end{array}$ & $\begin{array}{l}0.002 \\
(0.02)\end{array}$ & $\begin{array}{l}0.003 \\
(0.08)\end{array}$ & $\begin{array}{l}0.001 \\
(0.03)\end{array}$ \\
\hline Shock (other) & $\begin{array}{c}0.200^{* *} \\
(0.09)\end{array}$ & $\begin{array}{c}0.070^{* *} \\
(0.03)\end{array}$ & $\begin{array}{c}0.272^{* * *} \\
(0.10)\end{array}$ & $\begin{array}{c}0.097^{* * *} \\
(0.04)\end{array}$ & $\begin{array}{l}0.030 \\
(0.20)\end{array}$ & $\begin{array}{l}0.010 \\
(0.07)\end{array}$ \\
\hline Dist to Road & $\begin{array}{c}-0.006^{* * *} \\
(0.00)\end{array}$ & $\begin{array}{c}-0.002^{* *} \\
(0.00)\end{array}$ & $\begin{array}{c}-0.005^{* *} \\
(0.00)\end{array}$ & $\begin{array}{c}-0.001^{*} \\
(0.00)\end{array}$ & $\begin{array}{l}-0.008 \\
(0.01)\end{array}$ & $\begin{array}{l}-0.003 \\
(0.00)\end{array}$ \\
\hline Dist to Road2 & $\begin{array}{c}0.000^{* * *} \\
(0.00)\end{array}$ & & $\begin{array}{c}0.000^{* * *} \\
(0.00)\end{array}$ & & $\begin{array}{c}-0.000 \\
(0.00)\end{array}$ & \\
\hline Dist to Popcenter & $\begin{array}{c}-0.001 \\
(0.00)\end{array}$ & $\begin{array}{c}-0.000 \\
(0.00)\end{array}$ & $\begin{array}{c}-0.002 \\
(0.00)\end{array}$ & $\begin{array}{c}-0.001 \\
(0.00)\end{array}$ & $\begin{array}{l}0.003 \\
(0.01)\end{array}$ & $\begin{array}{l}0.001 \\
(0.00)\end{array}$ \\
\hline Dist to Popcenter2 & $\begin{array}{l}0.000 \\
(0.00)\end{array}$ & & $\begin{array}{l}0.000 \\
(0.00)\end{array}$ & & $\begin{array}{l}-0.000 \\
(0.00)\end{array}$ & \\
\hline Precipitation & $\begin{array}{l}-0.000 \\
(0.00)\end{array}$ & $\begin{array}{c}-0.000 \\
(0.00)\end{array}$ & $\begin{array}{c}-0.000 \\
(0.00)\end{array}$ & $\begin{array}{r}-0.000 \\
(0.00)\end{array}$ & $\begin{array}{l}-0.000 \\
(0.00)\end{array}$ & $\begin{array}{l}-0.000 \\
(0.00)\end{array}$ \\
\hline Malawi & $\begin{array}{c}-0.220^{* * *} \\
(0.05)\end{array}$ & $\begin{array}{c}-0.077^{* * *} \\
(0.02)\end{array}$ & $\begin{array}{c}-0.233^{* * *} \\
(0.06)\end{array}$ & $\begin{array}{c}-0.082^{* * *} \\
(0.02)\end{array}$ & $\begin{array}{c}-0.654^{* * *} \\
(0.12)\end{array}$ & $\begin{array}{c}-0.220^{* * *} \\
(0.04)\end{array}$ \\
\hline Niger & $\begin{array}{c}0.895^{* * *} \\
(0.08)\end{array}$ & $\begin{array}{c}0.312^{* * *} \\
(0.03)\end{array}$ & $\begin{array}{c}1.004^{* * *} \\
(0.09)\end{array}$ & $\begin{array}{c}0.352^{* * *} \\
(0.03)\end{array}$ & $\begin{array}{l}-0.024 \\
(0.16)\end{array}$ & $\begin{array}{l}-0.008 \\
(0.05)\end{array}$ \\
\hline Nigeria & $\begin{array}{c}0.824^{* * *} \\
(0.06)\end{array}$ & $\begin{array}{c}0.288^{* * *} \\
(0.02)\end{array}$ & $\begin{array}{c}0.810^{* * *} \\
(0.07)\end{array}$ & $\begin{array}{c}0.284^{* * *} \\
(0.02)\end{array}$ & $\begin{array}{c}0.411^{* * *} \\
(0.13)\end{array}$ & $\begin{array}{c}0.138^{* * *} \\
(0.04)\end{array}$ \\
\hline Tanzania & $\begin{array}{c}0.510^{* * *} \\
(0.06)\end{array}$ & $\begin{array}{c}0.178^{* * *} \\
(0.02)\end{array}$ & $\begin{array}{c}0.473^{* * *} \\
(0.07)\end{array}$ & $\begin{array}{c}0.166^{* * *} \\
(0.02)\end{array}$ & $\begin{array}{l}0.121 \\
(0.12)\end{array}$ & $\begin{array}{l}0.041 \\
(0.04)\end{array}$ \\
\hline Uganda & $\begin{array}{c}0.465^{* * *} \\
(0.07)\end{array}$ & $\begin{array}{c}0.162^{* * *} \\
(0.02)\end{array}$ & $\begin{array}{c}0.451^{* * *} \\
(0.07)\end{array}$ & $\begin{array}{c}0.158^{* * *} \\
(0.02)\end{array}$ & $\begin{array}{l}0.069 \\
(0.14)\end{array}$ & $\begin{array}{l}0.023 \\
(0.05)\end{array}$ \\
\hline _cons & $\begin{array}{c}-0.908^{* * *} \\
(0.18)\end{array}$ & & $\begin{array}{c}-1.225^{* * *} \\
(0.19)\end{array}$ & & $\begin{array}{l}-0.495 \\
(0.38)\end{array}$ & \\
\hline$N$ & 31,664 & 31,664 & 23,882 & 23,882 & 7,782 & 7,782 \\
\hline
\end{tabular}

Standard errors in parentheses. Survey weights included.

${ }^{*} p<0.1,{ }^{* *} p<0.05,{ }^{* * *} p<0.01$ 
Table 4 contains the results (average marginal effects) pertaining to rural households broken down by country. ${ }^{7}$ It shows that in Nigeria women-headed households are almost 12 percentage points more likely to start a non-farm enterprise compared to a male-headed household, while in the other countries gender of the household head is not a significant determinant. Age is a significant determinant of rural entrepreneurship in most countries, and returns a small negative impact meaning that entrepreneurship in rural Africa tends to be favored by younger households. The civil status (married) is associated with an increase in the likelihood of non-farm entrepreneurship in Nigeria, raising it by 11.8 percentage points, but with a decrease in the likelihood in Tanzania by 4.6 percentage points. Being able to "read \& write" is significant and positive in rural Malawi, Nigeria and Tanzania, suggesting that more educated household heads are more likely to start a non-farm enterprise in these countries. Household size is significant in four countries (Malawi, Nigeria, Tanzania and Uganda) with a positive coefficient, consistent with the findings elsewhere that larger households can allocate surplus labor into non-farm entrepreneurship. The number of "rooms" (a proxy for household wealth) is significant and positive for Ethiopia and Tanzania, and access to credit is significant and positive for Ethiopia and Malawi. These variables are however endogenous and we have to read them as a positive association.

Whether a household has been subject to food shortages over the past 12 months (a proxy for agricultural productivity and perhaps household income) impacts the likelihood differently across countries. It is significant and negative for Malawi and Niger, limiting non-farm enterprises, but positive and significant for Uganda. The results of shocks are, generally speaking, not significant in most countries, with some exceptions: idiosyncratic and geographic shocks return positive coefficients in Malawi, suggesting that households are pushed into non-farm enterprises in times of distress. Institutional shocks are not significant in any country, and "other shocks" are significant and positive for Niger. Finally, Table 4 indicates that household distance from a major road is significant for Nigeria and returns a lower probability of operating a non-farm enterprise (the probability decreases by 0.2 percentage points per $\mathrm{km}$ of distance away from a road). Distance to the next population center is significant for Malawi and Uganda, and equally decreases the likelihood.

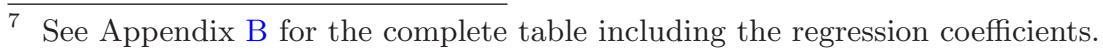


Table 4: Probit regressions - rural households only (average marginal effects)

\begin{tabular}{|c|c|c|c|c|c|c|}
\hline Dependent & (1) & $(2)$ & (3) & (4) & $(5)$ & (6) \\
\hline $\mathrm{NFE}$ & Ethiopia & Malawi & Niger & Nigeria & Tanzania & Uganda \\
\hline Female & $\begin{array}{r}-0.022 \\
(0.03)\end{array}$ & $\begin{array}{l}-0.004 \\
(0.02)\end{array}$ & $\begin{array}{l}-0.084 \\
(0.07)\end{array}$ & $\begin{array}{c}0.117^{* *} \\
(0.05)\end{array}$ & $\begin{array}{l}0.046 \\
(0.03)\end{array}$ & $\begin{array}{l}0.002 \\
(0.04)\end{array}$ \\
\hline Age & $\begin{array}{c}-0.002^{* * *} \\
(0.00)\end{array}$ & $\begin{array}{c}-0.001^{* * *} \\
(0.00)\end{array}$ & $\begin{array}{l}0.001 \\
(0.00)\end{array}$ & $\begin{array}{l}-0.001 \\
(0.00)\end{array}$ & $\begin{array}{c}-0.004^{* * *} \\
(0.00)\end{array}$ & $\begin{array}{c}-0.004^{* * *} \\
(0.00)\end{array}$ \\
\hline Married & $\begin{array}{r}-0.060 \\
(0.04)\end{array}$ & $\begin{array}{l}0.025 \\
(0.02)\end{array}$ & $\begin{array}{r}-0.047 \\
(0.06)\end{array}$ & $\begin{array}{c}0.118^{* * *} \\
(0.05)\end{array}$ & $\begin{array}{c}-0.046^{*} \\
(0.03)\end{array}$ & $\begin{array}{l}0.056 \\
(0.04)\end{array}$ \\
\hline Read \& Write & $\begin{array}{l}0.036 \\
(0.02)\end{array}$ & $\begin{array}{c}0.041^{* * *} \\
(0.01)\end{array}$ & $\begin{array}{l}0.033 \\
(0.03)\end{array}$ & $\begin{array}{c}0.126^{* * *} \\
(0.02)\end{array}$ & $\begin{array}{c}0.073^{* *} \\
(0.03)\end{array}$ & $\begin{array}{l}0.002 \\
(0.03)\end{array}$ \\
\hline HH Size & $\begin{array}{l}0.001 \\
(0.01)\end{array}$ & $\begin{array}{c}0.010^{* * *} \\
(0.00)\end{array}$ & $\begin{array}{l}-0.002 \\
(0.01)\end{array}$ & $\begin{array}{c}0.025^{* * *} \\
(0.01)\end{array}$ & $\begin{array}{c}0.018^{* * *} \\
(0.01)\end{array}$ & $\begin{array}{c}0.022^{* * *} \\
(0.01)\end{array}$ \\
\hline Share of Adults & $\begin{array}{c}-0.125^{* *} \\
(0.06)\end{array}$ & $\begin{array}{l}-0.005 \\
(0.03)\end{array}$ & $\begin{array}{c}-0.140^{*} \\
(0.07)\end{array}$ & $\begin{array}{l}0.086 \\
(0.05)\end{array}$ & $\begin{array}{l}0.105^{*} \\
(0.06)\end{array}$ & $\begin{array}{c}0.205^{* * *} \\
(0.07)\end{array}$ \\
\hline Rooms & $\begin{array}{c}0.034^{* * *} \\
(0.01)\end{array}$ & $\begin{array}{l}0.006 \\
(0.00)\end{array}$ & $\begin{array}{l}0.005 \\
(0.01)\end{array}$ & & $\begin{array}{c}0.029^{* * *} \\
(0.01)\end{array}$ & $\begin{array}{l}0.006 \\
(0.01)\end{array}$ \\
\hline Credit & $\begin{array}{c}0.089^{* * *} \\
(0.02)\end{array}$ & $\begin{array}{c}0.071^{* * *} \\
(0.01)\end{array}$ & & & $\begin{array}{l}0.033 \\
(0.05)\end{array}$ & \\
\hline Food Shortage & $\begin{array}{l}0.031 \\
(0.03)\end{array}$ & $\begin{array}{c}-0.033^{* * *} \\
(0.01)\end{array}$ & $\begin{array}{c}-0.094^{* * *} \\
(0.03)\end{array}$ & $\begin{array}{l}0.013 \\
(0.02)\end{array}$ & $\begin{array}{l}-0.005 \\
(0.03)\end{array}$ & $\begin{array}{c}0.070^{* *} \\
(0.04)\end{array}$ \\
\hline Shock (idiosyn.) & $\begin{array}{l}0.036 \\
(0.03)\end{array}$ & $\begin{array}{c}0.062^{* * *} \\
(0.01)\end{array}$ & $\begin{array}{l}0.020 \\
(0.04)\end{array}$ & $\begin{array}{r}-0.040 \\
(0.03)\end{array}$ & $\begin{array}{l}0.022 \\
(0.04)\end{array}$ & $\begin{array}{l}0.030 \\
(0.03)\end{array}$ \\
\hline Shock (geogr.) & $\begin{array}{r}-0.040 \\
(0.03)\end{array}$ & $\begin{array}{c}0.021^{* *} \\
(0.01)\end{array}$ & $\begin{array}{l}-0.017 \\
(0.03)\end{array}$ & $\begin{array}{r}-0.052 \\
(0.03)\end{array}$ & $\begin{array}{l}0.008 \\
(0.03)\end{array}$ & $\begin{array}{l}0.030 \\
(0.03)\end{array}$ \\
\hline Shock (institut.) & $\begin{array}{l}0.013 \\
(0.03)\end{array}$ & $\begin{array}{l}0.007 \\
(0.01)\end{array}$ & $\begin{array}{l}0.026 \\
(0.03)\end{array}$ & $\begin{array}{l}0.003 \\
(0.03)\end{array}$ & $\begin{array}{r}-0.020 \\
(0.03)\end{array}$ & $\begin{array}{c}-0.030 \\
(0.06)\end{array}$ \\
\hline Shock (other) & $\begin{array}{l}0.122 \\
(0.08)\end{array}$ & $\begin{array}{l}0.018 \\
(0.04)\end{array}$ & $\begin{array}{c}0.090^{* * *} \\
(0.03)\end{array}$ & $\begin{array}{l}0.016 \\
(0.09)\end{array}$ & $\begin{array}{l}-0.064 \\
(0.14)\end{array}$ & $\begin{array}{l}0.083 \\
(0.09)\end{array}$ \\
\hline Dist to Road & $\begin{array}{l}0.000 \\
(0.00)\end{array}$ & $\begin{array}{r}-0.000 \\
(0.00)\end{array}$ & $\begin{array}{c}-0.003 \\
(0.00)\end{array}$ & $\begin{array}{c}-0.002^{* *} \\
(0.00)\end{array}$ & $\begin{array}{l}-0.000 \\
(0.00)\end{array}$ & $\begin{array}{c}-0.004 \\
(0.00)\end{array}$ \\
\hline Dist to Popcenter & $\begin{array}{r}-0.000 \\
(0.00)\end{array}$ & $\begin{array}{c}-0.001^{* * *} \\
(0.00)\end{array}$ & $\begin{array}{l}-0.001 \\
(0.00)\end{array}$ & $\begin{array}{l}-0.001 \\
(0.00)\end{array}$ & $\begin{array}{l}-0.001 \\
(0.00)\end{array}$ & $\begin{array}{c}-0.003^{*} \\
(0.00)\end{array}$ \\
\hline Precipitation & $\begin{array}{l}0.000 \\
(0.00)\end{array}$ & $\begin{array}{r}-0.000 \\
(0.00)\end{array}$ & $\begin{array}{l}0.000 \\
(0.00)\end{array}$ & $\begin{array}{r}-0.000 \\
(0.00)\end{array}$ & $\begin{array}{r}-0.000 \\
(0.00)\end{array}$ & $\begin{array}{r}-0.000 \\
(0.00)\end{array}$ \\
\hline$N$ & 3,320 & 10,017 & 2,430 & 3,324 & 2,956 & 1,789 \\
\hline
\end{tabular}

Standard errors in parentheses. Survey weights included.

${ }^{*} p<0.1,{ }^{* *} p<0.05,{ }^{* * *} p<0.01$ 
We also screen the complete sample, broken down by countries, with a dummy indicating if households are located in rural areas. We focus on the dummy "rural" in the results of Table 8 (see Appendix B): the binary variable "rural" is highly significant for all countries with the exception of Niger, and negative, indicating that the probability of households running a non-farm enterprise is higher in urban areas of almost all countries, despite the fact that educated workers find easier wage employment in urban areas. The difference in percentage points varies from approximately 10 in Malawi and Uganda to almost 31 in Ethiopia. The coefficient of the interaction "female x rural" is marginally significant in Ethiopia, where it decreases the probability of operating a non-farm enterprise. Non-farm rural entrepreneurs in Africa suffer in comparison to urban entrepreneurs in their lack of amenities, densities and spillover effects, as well as in their greater lack of wage employment alternatives. This was reflected in our findings that urban households are more likely to operate enterprises throughout the year; and that being educated is more likely to lead to wage employment in urban areas.

Differences between the regressions pertaining to rural and urban households (see Table 10) show the heterogeneity in determinants: while gender is significant in rural Nigeria and returns a positive result, only the average marginal effect in Ethiopia is marginally significant in the urban parts the country. In the urban areas age seems to be less important compared to rural areas, where only the outcome for Niger is significant. Marital status is significant in the rural areas of Nigeria and Tanzania with contradicting coefficients, however in none of the urban areas. While the variable "read \& write" increases the probability of engaging in non-farm entrepreneurship in rural areas (where it is significant), the opposite is observed for urban areas. As we have already mentioned, this possibly indicates better opportunities of finding wage-employment in urban areas if the household head is educated. The results for "household size" are similar in both tables: the coefficient is positive and significant for most countries, suggesting the allocation of surplus labor into non-farm entrepreneurship. The share of adults is significant in rural Ethiopia, Niger and Uganda, with contradicting effects, but only significant in urban Ethiopia with a positive coefficient. The number of rooms has a positive and significant coefficient in rural Ethiopia and Tanzania, while it is not significant in urban areas. Credit is positive and significant in rural Ethiopia and Malawi, and positive and significant in urban Ethiopia. Experiencing food shortages have a significant and negative effect in rural and urban Malawi and rural Niger, and a significant and positive 
effect in rural Uganda. Experiencing a shock returns mixed results: in rural Malawi an idiosyncratic and a geographic shock return positive coefficients, as well as other shocks in rural Niger. Idiosyncratic shocks return significant coefficients in urban Malawi and Uganda with contradicting signs. A geographic shock is marginally significant for the average marginal effects in urban Ethiopia, and institutional shocks return significant and negative results in urban Malawi and significant and positive results in urban Niger. The same applies to other shocks: in urban Tanzania the coefficient is significant and positive and in urban Uganda it is significant and negative. Distance to the nearest road is significant and negative in rural Nigeria, and urban Uganda. Distance to the nearest population center is significant and negative in rural Malawi and rural Uganda, but in none of the urban areas. Precipitation is not significant in for all rural areas, but marginally significant and negative in urban Malawi and Nigeria.

\subsubsection{Country-Specific Analysis}

In this subsection we screen a number of country-specific variables that are not available for all, or at least for the majority, of the countries, or a differently coded per country. We focus on rural areas for the regressions (results are not reported, available upon request). We add a number of variables to the base regressions in Table 4 country by country, and receive significant results for the following countries and variables:

In Ethiopia the number of phones per household is significant at 5 percent and increases the probability of entrepreneurship by 3 percentage points per additional phone, which also presents an indication for household wealth. The household's religion is collectively significant at 1 percent. Taking the country's traditional religion as the reference category, we find that being a follower of Islam increases the probability of a household starting a non-farm enterprise by almost 16 percentage points; and being a Christian household increases this probability by almost 10 percentage points. Other variables, as for example, the existence of a commercial bank or a micro-finance institute in the community, the land use by households or the farm type, are insignificant.

In Niger the variable "nomad", indicating a nomadic lifestyle, decreases the

probability of operating a non-farm enterprise by 37 percentage points com- 
pared to non-nomad households. While the possibility that vehicles pass through the community throughout the year and the existence of electricity increases the likelihood of entrepreneurship (by 10 and 13 percentage points, respectively), the average marginal effect is negative for the number of phones per household, the existence of a bank or micro-finance institute, or an irrigation system in the community. While the first two variables could indicate a shift into other types of employment, an irrigation system probably results in more productive agricultural output, and labor could be allocated into agricultural work.

In Nigeria the number of beds per household is significant and increases the probability of entrepreneurship by 5 percentage point, per additional bed. The variable "plot" is significant and indicates if the household owns or cultivates a plot, and decreases the probability by almost 33 percentage points compared to households without a plot. The existence of a commercial bank or a micro-finance institute is however not significant in Nigeria.

In Tanzania the number of phones per household is significant and increases the probability of entrepreneurship by 7 percentage points per additional phone. Other additional variables are not significant in rural Tanzania, for example if households have livestock, or if they own or cultivate land.

In Uganda the number of phones per household is also significant and increases the probability of entrepreneurship by 4 percentage points per additional phone. Further significant variables, are the use of land, where the existence of pasture or wetland increases the probability by 19 percentage points in both cases, compared to land cultivation by villagers. If households cultivate land, the probability of entrepreneurship decreases by almost 28 percentage points. If households own land is however not significant.

Summarizing this section we found positive impact of number of phones and beds per households, with the exception of Niger, indicating a positive association between household wealth and entrepreneurship. The existence of a commercial bank and/or micro-finance institute in the community is not significant, or even results in negative marginal effects in the case of Niger. We also found that agriculture plays a role in some countries of our sample, for example in Niger via the irrigation system or in Uganda, where land use and land cultivation are significant. Other variables, for example, a nomadic lifestyle or religion, are country specific variables, and present habits and culture of a specific regional context. 


\section{Conclusion}

The patterns and determinants of non-farm entrepreneurship in rural Africa have been neglected in the scholarly literature. In this paper we address this lacuna by providing new empirical insights using the World Bank's LSMSISA data set which covers six Africa countries over the period 2005 - 2012. We find that rural non-farm enterprises are predominantly small, informal household enterprises, operating from the immediate surroundings of the household residence or in a traditional market, and provide mainly basic consumer goods and services to the local economy. The majority of rural non-farm enterprises do not operate continuously over the year, reflecting the impact of seasonality in agriculture on the allocation of household labor.

We furthermore establish that households operating a non-farm enterprise differ in individual capabilities, household characteristics, and institutional factors, compared to household that are not engaged in entrepreneurship. We found that both push and pull factors matter for the household's decision to operate a non-farm-enterprise. The effects of external shocks, the experiencing of food shortages, the distance that households are located from major roads and cities, and the importance of gender and marital status are all difficult to generalize. In this regard we find significant heterogeneity across the countries of our sample. This means that rural entrepreneurship is responsive to country-level circumstances and policies.

What is the policy take-away from these empirical findings? It seems that rural development policies in Sub-Saharan Africa have had little significant impact in fostering the structural change in rural areas that are consistent with notions of modern economic development. Being still a largely informal and survivalist sector, rural non-farm enterprises provide a risk-diversifying mechanism for households, similar to the 1960s. More than 50 years later rural non-farm entrepreneurship does still not contribute significantly to employment creation, rural development or income growth. The increase in the share of rural household income that emanates from this sector does not appear to be the outcome of successful policies, but the failure of policies to foster effective rural-urban migration and wage employment. The fact that enterprises in rural Africa are still fulfilling a risk management function by the year 2012, also suggests a sector that is reminiscent of economies at much lower gross national product (GNP) per capita. The comparatively high economic growth rates in Africa over the past decade has not been 
accompanied by significant structural economic change.

Although a risk-management function is important, given the shocks and seasonality that rural households in Africa have to contend with, we should not expect a significant contribution from rural non-farm entrepreneurship to employment creation and poverty reduction. This conclusion bears a resemblance to conclusions by other scholars (e.g. Rijkers and Söderbom, 2013; Start, 2001) who have pointed out that Africa's non-farm economy has a limited impact on poverty and growth. They have furthermore expressed concern about its informal and segmented labor markets with low, exploitative wages, frequent discrimination against women, and regular employment of children. Our results cannot, generally speaking, dispel such pessimistic evaluations of the state of non-farm entrepreneurship in rural Africa. 


\section{Acknowledgement}

We are grateful to Luc Christiaensen for his inspiration and many discussions on the topic, to Bob Rijkers for useful comments on an earlier draft, to Amparo Palacios-López for her assistance with the dataset and to Jonathan Kaminski and other participants in the World Bank's "Telling Facts from Myths - Agriculture in Africa" project for their comments and suggestions. The usual disclaimer applies. 


\section{References}

Abdulai, A. and Delgado, C. (1999). Determinants of Non-Farm Earnings of Farm-Based Husbands and Wives in Northern Ghana. American Journal of Agricultural Economics, 81 (1):117-130.

Ackah, C. (2013). Non-Farm Employment and Income in Rural Ghana. Journal of International Development, 25:325-339.

Babatunde, R. and Qaim, M. (2010). Impact of Off-Farm Income on Food Security and Nutrition in Nigeria. Food Policy, 35:303-311.

Barrett, C., Reardon, T., and Webb, P. (2001). Non-Farm Income Diversification and Household Livelihood Strategies in Rural Africa: Concepts, Issues, and Policy Implications. Food Policy, 26 (4):315-331.

Bayene, A. (2008). Determinants of Off-Farm Participation Decision of Farm Households in Ethiopia. Agrekon, 47 (1):140-161.

Bhaumik, S., Dimova, R., and Nugent, J. (2011). Off-Farm Labor Supply and Labor Markets in Rapidly Changing Circumstances: Bulgaria during Transition. Economic Systems, 35:378-389.

Canagarajah, S., Newman, C., and Bhattamishra, R. (2001). Non-Farm Income, Gender, and Inequality: Evidence from Rural Ghana and Uganda. Food Policy, 26 (4):405-420.

Davis, B., Winters, P., Carletto, G., Covarrubias, K., Quinones, E., Zezza, A., Stamoulis, K., Bonomi, G., and DiGuiseppe, S. (2007). Rural Income Generating Activities: A Cross-Country Comparison. ESA Working Paper No. 07-16, Rome: FAO.

Davis, J. and Bezemer, D. (2004). The Development of the Rural Non-Farm Economy in Developing Countries and Transition Economies: Key Emerging and Conceptual Issues. Chatham, UK: Natural Resources Institute.

Elbers, C. and Lanjouw, P. (2001). Intersectoral Transfer, Growth and Inequality in Rural Ecuador. World Development, 29 (3):481-496.

Escobal, J. (2001). The Determinants of Non-Farm Income Diversification in Rural Peru. World Development, 29 (3):497-508.

Fafchamps, M. and Shilpi, F. (2003). The Spatial Division of Labour in Nepal. Journal of Development Studies, 39 (6):23-66. 
Fox, L. and Sohnesen, T. (2013). Household Enterprises in Mozambique: Key to Poverty Reduction but not on the Development Agenda? Policy Research Working Paper 6570, Washington DC: The World Bank.

Haggblade, S., Hazell, P., and Brown, J. (1989). Farm-Non-Farm Linkages in Rural Sub-Saharan Africa. World Development, 17 (8):1173-1201.

Havnevik, K., Hrsmar, M., and Sandstrm, E. (2003). Rural Development and the Private Sector in Sub-Saharan Africa: SIDA's Experiences and Approaches in the 1990s. Stockholm: SIDA Evaluation 03/18.

Janvry, A. D. and Sadoulet, E. (2001). Income Strategies among Rural Households in Mexico: The Role of Off-Farm Activities. World Development, 29 (3):467-480.

Lanjouw, J. O. and Lanjouw, P. (2001). The Rural Non-Farm Sector: Issues and Evidence from Developing Countries. Agricultural Economics, 26:123.

Naudé, W. (2011). Entrepreneurship is not a Binding Constraint on Growth and Development in the Poorest Countries. World Development, 39 (1):33-44.

Reardon, T. (1997). Using Evidence of Household Income Diversification to Inform Study of the Rural Non-Farm Labor Market in Africa. World Development, 25 (5):735-747.

Reardon, T., Berdegue, J., Barrett, C., and Stamoulis, K. (2006). Household Income Diversification into Rural Non-Farm Activities. Baltimore: Johns Hopkins University Press.

Rijkers, B. and Costa, R. (2012). Gender and Rural Non-Farm Entrepreneurship. World Development, 40 (12):2411-2426.

Rijkers, B. and Söderbom, M. (2013). The Effects of Risk and Shocks on NonFarm Enterprise Development in Rural Ethiopia. World Development, 45:119-136.

Roepstorff, T. and Wiggens, S. (2011). New Global Realities Governing Agribusiness. UNIDO: Vienna.

Shi, X., Heerink, N., and Qu, F. (2007). Choices between different Off-Farm Employment Sub-Categories: An Empirical Analysis for Jiangxi Province, China. China Economic Review, 18:438-455. 
Start, D. (2001). The Rise and Fall of the Rural Non-Farm Economy: Poverty Impacts and Policy Options. Development Policy Review, 19 (4):491-505.

Wiggens, S. (2000). Interpreting Changes from the 1970s to the 1990s in African Agriculture through Village Studies. World Development, 28 (4):631-662. 


\section{A Appendix}

Summary statistics of section 4.2:

Table 5: Summary statistics probit model - overall

\begin{tabular}{|c|c|c|c|c|c|c|c|c|c|c|c|c|}
\hline Household & Eth & opia & & awi & & ser & $\mathrm{Niq}$ & eria & Tanz & ania & Ug: & ida \\
\hline operates a NFE & No & Yes & No & Yes & No & Yes & No & Yes & No & Yes & No & Yes \\
\hline Rural & 0.99 & 0.97 & 0.87 & 0.72 & 0.83 & 0.78 & 0.70 & 0.52 & 0.77 & 0.59 & 0.86 & 0.80 \\
\hline Female & 0.21 & 0.19 & 0.25 & 0.18 & 0.13 & 0.10 & 0.18 & 0.14 & 0.27 & 0.26 & 0.32 & 0.27 \\
\hline Age & 45.33 & 41.80 & 42.93 & 39.29 & 44.54 & 45.25 & 50.95 & 48.73 & 47.41 & 43.78 & 45.51 & 42.24 \\
\hline Married & 0.81 & 0.82 & 0.72 & 0.81 & 0.88 & 0.90 & 0.73 & 0.82 & 0.53 & 0.52 & 0.66 & 0.77 \\
\hline Read \& Write & 0.40 & 0.49 & 0.62 & 0.76 & 0.32 & 0.34 & 0.58 & 0.71 & 0.69 & 0.81 & 0.66 & 0.68 \\
\hline Household Size & 5.04 & 5.35 & 4.49 & 5.00 & 6.05 & 6.80 & 4.87 & 5.69 & 4.85 & 5.40 & 5.86 & 6.71 \\
\hline Share of Adults & 0.59 & 0.54 & 0.60 & 0.57 & 0.55 & 0.51 & 0.69 & 0.63 & 0.64 & 0.62 & 0.62 & 0.58 \\
\hline Rooms & 1.64 & 1.82 & 2.50 & 2.75 & 2.55 & 2.76 & & & 3.22 & 3.44 & 2.76 & 2.81 \\
\hline Credit & 0.25 & 0.37 & 0.12 & 0.19 & & & & & 0.08 & 0.13 & & \\
\hline Food Shortage & 0.32 & 0.37 & 0.49 & 0.41 & 0.41 & 0.33 & 0.28 & 0.32 & 0.20 & 0.20 & 0.21 & 0.24 \\
\hline Shock (idiosyn.) & 0.17 & 0.19 & 0.21 & 0.29 & 0.19 & 0.19 & 0.20 & 0.17 & 0.18 & 0.20 & 0.13 & 0.14 \\
\hline Shock (geogr.) & 0.24 & 0.22 & 0.44 & 0.40 & 0.38 & 0.33 & 0.11 & 0.07 & 0.17 & 0.15 & 0.26 & 0.30 \\
\hline Shock (institut.) & 0.34 & 0.37 & 0.43 & 0.43 & 0.30 & 0.35 & 0.10 & 0.09 & 0.22 & 0.25 & 0.05 & 0.06 \\
\hline Shock (other) & 0.02 & 0.04 & 0.02 & 0.02 & 0.14 & 0.19 & 0.01 & 0.02 & 0.01 & 0.01 & 0.02 & 0.02 \\
\hline Dist to Road & 14.98 & 14.93 & 9.70 & 7.29 & 13.60 & 8.89 & 14.47 & 10.84 & 17.15 & 14.52 & 7.78 & 7.00 \\
\hline Dist to Popcenter & 36.74 & 33.79 & 34.13 & 28.40 & 56.70 & 51.09 & 18.91 & 15.54 & 45.96 & 39.83 & 22.50 & 21.93 \\
\hline Precipitation & $1,166.20$ & $1,206.96$ & $1,067.49$ & $1,043.17$ & 387.09 & 406.95 & $1,514.74$ & $1,475.12$ & $1,060.38$ & $1,058.18$ & $1,244.05$ & $1,232.79$ \\
\hline $\mathrm{N}$ & 2,757 & 1,212 & 9,699 & 2,572 & 1,543 & 2,425 & 2,185 & 2,815 & 2,145 & 1,857 & 1,409 & 1,307 \\
\hline
\end{tabular}

Source: Authors' calculations based on LSMS-ISA data (weighted shares). Bolded coefficents indicate differences between households with and without a non-farm enterprise that are significant at a 5 percent level. 
Table 6: Summary statistics probit model - rural

\begin{tabular}{|c|c|c|c|c|c|c|c|c|c|c|c|c|}
\hline \multirow{2}{*}{$\begin{array}{l}\text { Household } \\
\text { operates a NFE }\end{array}$} & \multicolumn{2}{|c|}{ Ethiopia } & \multicolumn{2}{|c|}{ Malawi } & \multicolumn{2}{|c|}{ Niger } & \multicolumn{2}{|c|}{ Nigeria } & \multicolumn{2}{|c|}{ Tanzania } & \multicolumn{2}{|c|}{ Uganda } \\
\hline & No & Yes & No & Yes & No & Yes & No & Yes & No & Yes & No & Yes \\
\hline Female & 0.20 & 0.18 & 0.26 & 0.19 & 0.11 & 0.09 & 0.17 & 0.12 & 0.25 & 0.24 & 0.31 & 0.25 \\
\hline Age & 45.37 & 41.77 & 43.50 & 39.84 & 44.19 & 44.96 & 51.38 & 48.98 & 48.95 & 44.99 & 46.28 & 42.33 \\
\hline Married & 0.81 & 0.82 & 0.72 & 0.81 & 0.90 & 0.91 & 0.76 & 0.85 & 0.57 & 0.54 & 0.68 & 0.79 \\
\hline Read \& Write & 0.40 & 0.49 & 0.58 & 0.71 & 0.25 & 0.31 & 0.48 & 0.63 & 0.64 & 0.74 & 0.63 & 0.64 \\
\hline Household Size & 5.05 & 5.37 & 4.52 & 5.00 & 6.17 & 6.84 & 5.19 & 6.19 & 5.19 & 5.90 & 5.98 & 6.79 \\
\hline Share of Adults & 0.59 & 0.54 & 0.59 & 0.55 & 0.53 & 0.50 & 0.65 & 0.60 & 0.61 & 0.58 & 0.60 & 0.57 \\
\hline Rooms & 1.64 & 1.81 & 2.44 & 2.63 & 2.50 & 2.76 & & & 3.37 & 3.82 & 2.80 & 2.84 \\
\hline Credit & 0.26 & 0.37 & 0.11 & 0.19 & & & & & 0.08 & 0.11 & & \\
\hline Food Shortage & 0.32 & 0.37 & 0.52 & 0.47 & 0.47 & 0.38 & 0.26 & 0.27 & 0.21 & 0.21 & 0.22 & 0.27 \\
\hline Shock (idiosyn.) & 0.17 & 0.19 & 0.22 & 0.31 & 0.19 & 0.19 & 0.21 & 0.18 & 0.15 & 0.16 & 0.13 & 0.16 \\
\hline Shock (geogr.) & 0.24 & 0.22 & 0.48 & 0.52 & 0.45 & 0.40 & 0.14 & 0.11 & 0.18 & 0.17 & 0.29 & 0.35 \\
\hline Shock (institut.) & 0.34 & 0.38 & 0.45 & 0.50 & 0.32 & 0.36 & 0.11 & 0.10 & 0.21 & 0.21 & 0.05 & 0.05 \\
\hline Shock (other) & 0.02 & 0.04 & 0.02 & 0.02 & 0.15 & 0.21 & 0.01 & 0.01 & 0.01 & 0.00 & 0.02 & 0.02 \\
\hline Dist to Road & 14.98 & 14.97 & 10.84 & 9.37 & 16.26 & 11.09 & 18.33 & 16.75 & 20.80 & 21.16 & 8.55 & 8.11 \\
\hline Dist to Popcenter & 36.69 & 33.44 & 37.69 & 35.49 & 65.86 & 61.96 & 23.89 & 22.92 & 53.91 & 52.77 & 24.78 & 25.31 \\
\hline Precipitation & $1,166.26$ & $1,206.95$ & $1,068.41$ & $1,049.48$ & 376.69 & 401.14 & $1,470.53$ & $1,417.18$ & $1,071.51$ & $1,065.28$ & $1,238.64$ & $1,224.92$ \\
\hline $\mathrm{N}$ & 2,547 & 919 & 8,283 & 1,755 & 1,003 & 1,427 & 1,673 & 1,707 & 1,584 & 1,083 & 1,152 & 953 \\
\hline
\end{tabular}

Source: Authors' calculations based on LSMS-ISA data (weighted shares). Bolded coefficents indicate differences between households with and without a non-farm enterprise that are significant at a 5 percent level. 
Table 7: Summary statistics probit model - urban

\begin{tabular}{|c|c|c|c|c|c|c|c|c|c|c|c|c|}
\hline \multirow{2}{*}{$\begin{array}{l}\text { Household } \\
\text { operates a NFE }\end{array}$} & \multicolumn{2}{|c|}{ Ethiopia } & \multicolumn{2}{|c|}{ Malawi } & \multicolumn{2}{|c|}{ Niger } & \multicolumn{2}{|c|}{ Nigeria } & \multicolumn{2}{|c|}{ Tanzania } & \multicolumn{2}{|c|}{ Uganda } \\
\hline & No & Yes & No & Yes & No & Yes & No & Yes & No & Yes & No & Yes \\
\hline Female & 0.30 & 0.38 & 0.19 & 0.15 & 0.18 & 0.15 & 0.21 & 0.17 & 0.34 & 0.29 & 0.35 & 0.37 \\
\hline Age & 37.43 & 42.87 & 39.00 & 37.86 & 46.19 & 46.30 & 49.97 & 48.46 & 41.70 & 42.25 & 40.63 & 41.91 \\
\hline Married & 0.62 & 0.67 & 0.71 & 0.80 & 0.76 & 0.84 & 0.66 & 0.79 & 0.39 & 0.51 & 0.52 & 0.69 \\
\hline Read \& Write & 0.71 & 0.62 & 0.89 & 0.91 & 0.64 & 0.46 & 0.80 & 0.80 & 0.84 & 0.91 & 0.84 & 0.84 \\
\hline Household Size & 3.26 & 4.44 & 4.28 & 4.98 & 5.52 & 6.65 & 4.13 & 5.14 & 3.83 & 4.72 & 5.10 & 6.37 \\
\hline Share of Adults & 0.73 & 0.64 & 0.66 & 0.61 & 0.63 & 0.57 & 0.77 & 0.66 & 0.73 & 0.68 & 0.75 & 0.64 \\
\hline Rooms & 2.07 & 2.30 & 2.87 & 3.08 & 2.80 & 2.78 & & & 2.65 & 2.92 & 2.44 & 2.69 \\
\hline Credit & 0.13 & 0.26 & 0.19 & 0.20 & & & & & 0.12 & 0.18 & & \\
\hline Food Shortage & 0.23 & 0.20 & 0.29 & 0.25 & 0.13 & 0.15 & 0.33 & 0.38 & 0.17 & 0.20 & 0.17 & 0.13 \\
\hline Shock (idiosyn.) & 0.14 & 0.15 & 0.15 & 0.25 & 0.19 & 0.20 & 0.16 & 0.16 & 0.26 & 0.26 & 0.15 & 0.09 \\
\hline Shock (geogr.) & 0.09 & 0.05 & 0.11 & 0.10 & 0.07 & 0.06 & 0.03 & 0.03 & 0.13 & 0.12 & 0.08 & 0.11 \\
\hline Shock (institut.) & 0.18 & 0.20 & 0.28 & 0.25 & 0.25 & 0.33 & 0.09 & 0.08 & 0.25 & 0.29 & 0.03 & 0.06 \\
\hline Shock (other) & 0.02 & 0.01 & 0.02 & 0.02 & 0.10 & 0.11 & 0.02 & 0.03 & 0.00 & 0.02 & 0.02 & 0.01 \\
\hline Dist to Road & 15.21 & 13.53 & 1.81 & 1.88 & 1.05 & 0.92 & 5.57 & 4.50 & 4.86 & 4.75 & 2.45 & 2.84 \\
\hline Dist to Popcenter & 45.04 & 46.89 & 9.46 & 9.96 & 13.39 & 11.71 & 7.43 & 7.64 & 18.94 & 21.18 & 6.68 & 9.29 \\
\hline Precipitation & $1,155.65$ & $1,207.70$ & $1,061.12$ & $1,026.76$ & 436.25 & 428.00 & $1,616.71$ & $1,537.23$ & $1,028.66$ & $1,049.29$ & $1,281.45$ & $1,262.21$ \\
\hline $\mathrm{N}$ & 210 & 293 & 1,416 & 817 & 540 & 998 & 512 & 1,108 & 655 & 876 & 257 & 354 \\
\hline
\end{tabular}

Source: Authors' calculations based on LSMS-ISA data (weighted shares). Bolded coefficents indicate differences between households with and without a non-farm enterprise that are significant at a 5 percent level. 


\section{B Appendix}

Table 8: Probit regressions - all households (coefficients and average marginal effects)

\begin{tabular}{|c|c|c|c|c|c|c|}
\hline $\begin{array}{l}\text { Dependent } \\
\text { NFE }\end{array}$ & $\begin{array}{c}(1) \\
\text { Ethiopia }\end{array}$ & $\begin{array}{c}(2) \\
\text { AME }\end{array}$ & $\begin{array}{c}(3) \\
\text { Malawi }\end{array}$ & $\begin{array}{c}(4) \\
\text { AME }\end{array}$ & $\begin{array}{c}(5) \\
\text { Niger }\end{array}$ & $\begin{array}{c}(6) \\
\text { AME }\end{array}$ \\
\hline Rural & $\begin{array}{c}-0.808^{* * *} \\
(0.14)\end{array}$ & $\begin{array}{c}-0.309^{* * *} \\
(0.05)\end{array}$ & $\begin{array}{c}-0.357^{* * *} \\
(0.07)\end{array}$ & $\begin{array}{c}-0.103^{* * *} \\
(0.02)\end{array}$ & $\begin{array}{l}0.139 \\
(0.15)\end{array}$ & $\begin{array}{l}0.050 \\
(0.05)\end{array}$ \\
\hline Female & $\begin{array}{l}0.264 \\
(0.17)\end{array}$ & $\begin{array}{r}-0.019 \\
(0.03)\end{array}$ & $\begin{array}{l}0.010 \\
(0.15)\end{array}$ & $\begin{array}{c}0.002 \\
(0.02)\end{array}$ & $\begin{array}{r}-0.117 \\
(0.14)\end{array}$ & $\begin{array}{r}-0.048 \\
(0.05)\end{array}$ \\
\hline Rural x Female & $\begin{array}{c}-0.337^{*} \\
(0.18)\end{array}$ & & $\begin{array}{c}-0.004 \\
(0.15)\end{array}$ & & $\begin{array}{l}-0.017 \\
(0.15)\end{array}$ & \\
\hline Age & $\begin{array}{l}-0.011 \\
(0.01)\end{array}$ & $\begin{array}{c}-0.002^{* * *} \\
(0.00)\end{array}$ & $\begin{array}{l}0.004 \\
(0.01)\end{array}$ & $\begin{array}{c}-0.001^{* * *} \\
(0.00)\end{array}$ & $\begin{array}{l}0.022^{*} \\
(0.01)\end{array}$ & $\begin{array}{l}0.001 \\
(0.00)\end{array}$ \\
\hline Age2 & $\begin{array}{l}0.000 \\
(0.00)\end{array}$ & & $\begin{array}{c}-0.000^{*} \\
(0.00)\end{array}$ & & $\begin{array}{c}-0.000^{*} \\
(0.00)\end{array}$ & \\
\hline Married & $\begin{array}{c}-0.195 \\
(0.13)\end{array}$ & $\begin{array}{c}-0.059 \\
(0.04)\end{array}$ & $\begin{array}{c}0.122^{* *} \\
(0.06)\end{array}$ & $\begin{array}{c}0.031^{* *} \\
(0.02)\end{array}$ & $\begin{array}{l}0.016 \\
(0.13)\end{array}$ & $\begin{array}{l}0.006 \\
(0.05)\end{array}$ \\
\hline Read \& Write & $\begin{array}{l}0.121 \\
(0.08)\end{array}$ & $\begin{array}{l}0.035 \\
(0.02)\end{array}$ & $\begin{array}{c}0.153^{* * *} \\
(0.04)\end{array}$ & $\begin{array}{c}0.039^{* * *} \\
(0.01)\end{array}$ & $\begin{array}{c}-0.036 \\
(0.07)\end{array}$ & $\begin{array}{c}-0.013 \\
(0.03)\end{array}$ \\
\hline HH Size & $\begin{array}{l}-0.068 \\
(0.07)\end{array}$ & $\begin{array}{l}0.002 \\
(0.01)\end{array}$ & $\begin{array}{c}0.078^{* *} \\
(0.03)\end{array}$ & $\begin{array}{c}0.013^{* * *} \\
(0.00)\end{array}$ & $\begin{array}{c}-0.026 \\
(0.03)\end{array}$ & $\begin{array}{l}0.004 \\
(0.01)\end{array}$ \\
\hline HH Size2 & $\begin{array}{l}0.007 \\
(0.01)\end{array}$ & & $\begin{array}{c}-0.003 \\
(0.00)\end{array}$ & & $\begin{array}{c}0.003^{*} \\
(0.00)\end{array}$ & \\
\hline Share of Adults & $\begin{array}{c}-0.427^{* *} \\
(0.20)\end{array}$ & $\begin{array}{c}-0.123^{* *} \\
(0.06)\end{array}$ & $\begin{array}{l}0.025 \\
(0.11)\end{array}$ & $\begin{array}{l}0.007 \\
(0.03)\end{array}$ & $\begin{array}{c}-0.370^{* *} \\
(0.16)\end{array}$ & $\begin{array}{c}-0.134^{* *} \\
(0.06)\end{array}$ \\
\hline Rooms & $\begin{array}{c}0.115^{* * *} \\
(0.04)\end{array}$ & $\begin{array}{c}0.033^{* * *} \\
(0.01)\end{array}$ & $\begin{array}{l}0.031^{*} \\
(0.02)\end{array}$ & $\begin{array}{c}0.008^{* *} \\
(0.00)\end{array}$ & $\begin{array}{c}-0.009 \\
(0.03)\end{array}$ & $\begin{array}{c}-0.003 \\
(0.01)\end{array}$ \\
\hline Credit & $\begin{array}{c}0.297^{* * *} \\
(0.07)\end{array}$ & $\begin{array}{c}0.090^{* * *} \\
(0.02)\end{array}$ & $\begin{array}{c}0.202^{* * *} \\
(0.05)\end{array}$ & $\begin{array}{c}0.056^{* * *} \\
(0.02)\end{array}$ & & \\
\hline Food Shortage & $\begin{array}{l}0.104 \\
(0.09)\end{array}$ & $\begin{array}{l}0.030 \\
(0.03)\end{array}$ & $\begin{array}{c}-0.144^{* * *} \\
(0.03)\end{array}$ & $\begin{array}{c}-0.037^{* * *} \\
(0.01)\end{array}$ & $\begin{array}{c}-0.223^{* * *} \\
(0.06)\end{array}$ & $\begin{array}{c}-0.081^{* * *} \\
(0.02)\end{array}$ \\
\hline Shock (idiosyn.) & $\begin{array}{l}0.116 \\
(0.08)\end{array}$ & $\begin{array}{l}0.035 \\
(0.02)\end{array}$ & $\begin{array}{c}0.275^{* * *} \\
(0.04)\end{array}$ & $\begin{array}{c}0.076^{* * *} \\
(0.01)\end{array}$ & $\begin{array}{l}0.057 \\
(0.09)\end{array}$ & $\begin{array}{l}0.021 \\
(0.03)\end{array}$ \\
\hline Shock (geogr.) & $\begin{array}{l}-0.145 \\
(0.12)\end{array}$ & $\begin{array}{l}-0.041 \\
(0.03)\end{array}$ & $\begin{array}{c}0.088^{* *} \\
(0.04)\end{array}$ & $\begin{array}{c}0.023^{* *} \\
(0.01)\end{array}$ & $\begin{array}{l}-0.079 \\
(0.08)\end{array}$ & $\begin{array}{l}-0.029 \\
(0.03)\end{array}$ \\
\hline Shock (institut.) & $\begin{array}{l}0.047 \\
(0.10)\end{array}$ & $\begin{array}{l}0.014 \\
(0.03)\end{array}$ & $\begin{array}{r}-0.012 \\
(0.04)\end{array}$ & $\begin{array}{l}-0.003 \\
(0.01)\end{array}$ & $\begin{array}{l}0.117 \\
(0.07)\end{array}$ & $\begin{array}{l}0.042 \\
(0.03)\end{array}$ \\
\hline Shock (other) & $\begin{array}{l}0.372^{*} \\
(0.21)\end{array}$ & $\begin{array}{l}0.120 \\
(0.07)\end{array}$ & $\begin{array}{l}0.031 \\
(0.13)\end{array}$ & $\begin{array}{l}0.008 \\
(0.04)\end{array}$ & $\begin{array}{c}0.221^{* * *} \\
(0.08)\end{array}$ & $\begin{array}{c}0.078^{* * *} \\
(0.03)\end{array}$ \\
\hline Dist to Road & $\begin{array}{l}0.000 \\
(0.01)\end{array}$ & $\begin{array}{l}0.000 \\
(0.00)\end{array}$ & $\begin{array}{c}-0.001 \\
(0.01)\end{array}$ & $\begin{array}{c}-0.000 \\
(0.00)\end{array}$ & $\begin{array}{c}-0.009 \\
(0.01)\end{array}$ & $\begin{array}{l}-0.004 \\
(0.00)\end{array}$ \\
\hline Dist to Road2 & $\begin{array}{l}0.000 \\
(0.00)\end{array}$ & & $\begin{array}{l}-0.000 \\
(0.00)\end{array}$ & & $\begin{array}{l}-0.000 \\
(0.00)\end{array}$ & \\
\hline Dist to Popcenter & $\begin{array}{l}-0.001 \\
(0.00)\end{array}$ & $\begin{array}{l}-0.000 \\
(0.00)\end{array}$ & $\begin{array}{c}-0.010^{* * *} \\
(0.00)\end{array}$ & $\begin{array}{c}-0.001^{* * *} \\
(0.00)\end{array}$ & $\begin{array}{l}-0.004 \\
(0.00)\end{array}$ & $\begin{array}{l}-0.001 \\
(0.00)\end{array}$ \\
\hline Dist to Popcenter2 & $\begin{array}{r}-0.000 \\
(0.00)\end{array}$ & & $\begin{array}{c}0.000^{* * *} \\
(0.00)\end{array}$ & & $\begin{array}{l}0.000 \\
(0.00)\end{array}$ & \\
\hline Precipitation & $\begin{array}{l}0.000 \\
(0.00)\end{array}$ & $\begin{array}{l}0.000 \\
(0.00)\end{array}$ & $\begin{array}{c}-0.000^{* *} \\
(0.00)\end{array}$ & $\begin{array}{c}-0.000^{* *} \\
(0.00)\end{array}$ & $\begin{array}{l}0.000 \\
(0.00)\end{array}$ & $\begin{array}{l}0.000 \\
(0.00)\end{array}$ \\
\hline _cons & $\begin{array}{l}0.544 \\
(0.47)\end{array}$ & & $\begin{array}{c}-0.784^{* * *} \\
(0.22)\end{array}$ & & $\begin{array}{l}0.048 \\
(0.42)\end{array}$ & \\
\hline$N$ & 3,797 & 3,797 & 12,246 & 12,246 & 3,968 & 3,968 \\
\hline
\end{tabular}




\begin{tabular}{|c|c|c|c|c|c|c|}
\hline & $\begin{array}{c}(7) \\
\text { Nigeria } \\
\end{array}$ & $\begin{array}{c}(8) \\
\text { AME } \\
\end{array}$ & $\begin{array}{c}(9) \\
\text { Tanzania } \\
\end{array}$ & $\begin{array}{c}(10) \\
\text { AME }\end{array}$ & $\begin{array}{c}\text { (11) } \\
\text { Uganda }\end{array}$ & $\begin{array}{c}(12) \\
\text { AME }\end{array}$ \\
\hline Rural & $\begin{array}{c}-0.386^{* * *} \\
(0.09)\end{array}$ & $\begin{array}{c}-0.140^{* * *} \\
(0.03)\end{array}$ & $\begin{array}{c}-0.577^{* * *} \\
(0.09)\end{array}$ & $\begin{array}{c}-0.204^{* * *} \\
(0.03)\end{array}$ & $\begin{array}{c}-0.235^{* *} \\
(0.12)\end{array}$ & $\begin{array}{c}-0.097^{* *} \\
(0.04)\end{array}$ \\
\hline Female & $\begin{array}{c}0.259^{*} \\
(0.14)\end{array}$ & $\begin{array}{c}0.090^{* * *} \\
(0.03)\end{array}$ & $\begin{array}{l}0.001 \\
(0.10)\end{array}$ & $\begin{array}{c}0.038 \\
(0.03)\end{array}$ & $\begin{array}{l}0.082 \\
(0.17)\end{array}$ & $\begin{array}{l}0.001 \\
(0.03)\end{array}$ \\
\hline Rural x Female & $\begin{array}{l}-0.001 \\
(0.15)\end{array}$ & & $\begin{array}{l}0.149 \\
(0.12)\end{array}$ & & $\begin{array}{l}-0.092 \\
(0.18)\end{array}$ & \\
\hline Age & $\begin{array}{c}0.023^{* *} \\
(0.01)\end{array}$ & $\begin{array}{l}-0.001 \\
(0.00)\end{array}$ & $\begin{array}{l}0.010 \\
(0.01)\end{array}$ & $\begin{array}{c}-0.003^{* * *} \\
(0.00)\end{array}$ & $\begin{array}{c}0.035^{* *} \\
(0.01)\end{array}$ & $\begin{array}{c}-0.003^{* * *} \\
(0.00)\end{array}$ \\
\hline Age2 & $\begin{array}{c}-0.000^{* * *} \\
(0.00)\end{array}$ & & $\begin{array}{c}-0.000^{* *} \\
(0.00)\end{array}$ & & $\begin{array}{c}-0.000^{* * *} \\
(0.00)\end{array}$ & \\
\hline Married & $\begin{array}{c}0.251^{* * * *} \\
(0.09)\end{array}$ & $\begin{array}{c}0.092^{* * *} \\
(0.03)\end{array}$ & $\begin{array}{l}-0.041 \\
(0.06)\end{array}$ & $\begin{array}{c}-0.015 \\
(0.02)\end{array}$ & $\begin{array}{l}0.134 \\
(0.11)\end{array}$ & $\begin{array}{l}0.049 \\
(0.04)\end{array}$ \\
\hline Read \& Write & $\begin{array}{c}0.181^{* * * *} \\
(0.06)\end{array}$ & $\begin{array}{c}0.066^{* * *} \\
(0.02)\end{array}$ & $\begin{array}{c}0.208^{* * *} \\
(0.08)\end{array}$ & $\begin{array}{c}0.077^{* * *} \\
(0.03)\end{array}$ & $\begin{array}{l}0.010 \\
(0.07)\end{array}$ & $\begin{array}{l}0.004 \\
(0.03)\end{array}$ \\
\hline HH Size & $\begin{array}{c}0.100^{* * *} \\
(0.03)\end{array}$ & $\begin{array}{c}0.024^{* * *} \\
(0.00)\end{array}$ & $\begin{array}{c}0.077^{* * * *} \\
(0.02)\end{array}$ & $\begin{array}{c}0.023^{* * *} \\
(0.01)\end{array}$ & $\begin{array}{c}0.135^{* * *} \\
(0.03)\end{array}$ & $\begin{array}{c}0.023^{* * *} \\
(0.00)\end{array}$ \\
\hline HH Size2 & $\begin{array}{c}-0.003^{* *} \\
(0.00)\end{array}$ & & $\begin{array}{c}-0.001^{* *} \\
(0.00)\end{array}$ & & $\begin{array}{c}-0.005^{* * *} \\
(0.00)\end{array}$ & \\
\hline Share of Adults & $\begin{array}{c}-0.042 \\
(0.14)\end{array}$ & $\begin{array}{l}-0.015 \\
(0.05)\end{array}$ & $\begin{array}{l}0.136 \\
(0.14)\end{array}$ & $\begin{array}{l}0.050 \\
(0.05)\end{array}$ & $\begin{array}{c}0.377^{* *} \\
(0.17)\end{array}$ & $\begin{array}{c}0.137^{* *} \\
(0.06)\end{array}$ \\
\hline Rooms & & & $\begin{array}{c}0.057^{* * *} \\
(0.02)\end{array}$ & $\begin{array}{c}0.021^{* * *} \\
(0.01)\end{array}$ & $\begin{array}{l}0.014 \\
(0.02)\end{array}$ & $\begin{array}{l}0.005 \\
(0.01)\end{array}$ \\
\hline Credit & & & $\begin{array}{c}0.153^{*} \\
(0.09)\end{array}$ & $\begin{array}{c}0.057^{*} \\
(0.03)\end{array}$ & & \\
\hline Food Shortage & $\begin{array}{l}0.068 \\
(0.06)\end{array}$ & $\begin{array}{l}0.024 \\
(0.02)\end{array}$ & $\begin{array}{l}0.034 \\
(0.06)\end{array}$ & $\begin{array}{l}0.012 \\
(0.02)\end{array}$ & $\begin{array}{c}0.149^{*} \\
(0.09)\end{array}$ & $\begin{array}{c}0.055^{*} \\
(0.03)\end{array}$ \\
\hline Shock (idiosyn.) & $\begin{array}{l}-0.071 \\
(0.06)\end{array}$ & $\begin{array}{c}-0.026 \\
(0.02)\end{array}$ & $\begin{array}{l}0.019 \\
(0.07)\end{array}$ & $\begin{array}{l}0.007 \\
(0.03)\end{array}$ & $\begin{array}{c}-0.014 \\
(0.08)\end{array}$ & $\begin{array}{l}-0.005 \\
(0.03)\end{array}$ \\
\hline Shock (geogr.) & $\begin{array}{c}-0.160^{*} \\
(0.08)\end{array}$ & $\begin{array}{c}-0.058^{*} \\
(0.03)\end{array}$ & $\begin{array}{r}-0.020 \\
(0.07)\end{array}$ & $\begin{array}{c}-0.008 \\
(0.03)\end{array}$ & $\begin{array}{l}0.103 \\
(0.08)\end{array}$ & $\begin{array}{l}0.038 \\
(0.03)\end{array}$ \\
\hline Shock (institut.) & $\begin{array}{c}-0.036 \\
(0.07)\end{array}$ & $\begin{array}{c}-0.013 \\
(0.03)\end{array}$ & $\begin{array}{l}0.001 \\
(0.07)\end{array}$ & $\begin{array}{l}0.000 \\
(0.03)\end{array}$ & $\begin{array}{c}-0.034 \\
(0.14)\end{array}$ & $\begin{array}{r}-0.012 \\
(0.05)\end{array}$ \\
\hline Shock (other) & $\begin{array}{l}0.012 \\
(0.19)\end{array}$ & $\begin{array}{l}0.004 \\
(0.07)\end{array}$ & $\begin{array}{l}0.275 \\
(0.28)\end{array}$ & $\begin{array}{l}0.102 \\
(0.10)\end{array}$ & $\begin{array}{l}0.035 \\
(0.22)\end{array}$ & $\begin{array}{l}0.013 \\
(0.08)\end{array}$ \\
\hline Dist to Road & $\begin{array}{c}-0.009^{*} \\
(0.00)\end{array}$ & $\begin{array}{c}-0.003^{* *} \\
(0.00)\end{array}$ & $\begin{array}{c}-0.004 \\
(0.00)\end{array}$ & $\begin{array}{c}-0.001 \\
(0.00)\end{array}$ & $\begin{array}{c}-0.044^{* * *} \\
(0.02)\end{array}$ & $\begin{array}{c}-0.007^{* *} \\
(0.00)\end{array}$ \\
\hline Dist to Road2 & $\begin{array}{l}0.000 \\
(0.00)\end{array}$ & & $\begin{array}{l}0.000 \\
(0.00)\end{array}$ & & $\begin{array}{c}0.002^{* * *} \\
(0.00)\end{array}$ & \\
\hline Dist to Popcenter & $\begin{array}{r}-0.000 \\
(0.01)\end{array}$ & $\begin{array}{c}-0.000 \\
(0.00)\end{array}$ & $\begin{array}{l}0.001 \\
(0.00)\end{array}$ & $\begin{array}{r}-0.000 \\
(0.00)\end{array}$ & $\begin{array}{c}-0.018^{* *} \\
(0.01)\end{array}$ & $\begin{array}{c}-0.002^{*} \\
(0.00)\end{array}$ \\
\hline Dist to Popcenter2 & $\begin{array}{l}-0.000 \\
(0.00)\end{array}$ & & $\begin{array}{r}-0.000 \\
(0.00)\end{array}$ & & $\begin{array}{c}0.000^{* *} \\
(0.00)\end{array}$ & \\
\hline Precipitation & $\begin{array}{c}-0.000^{*} \\
(0.00)\end{array}$ & $\begin{array}{c}-0.000^{*} \\
(0.00)\end{array}$ & $\begin{array}{l}0.000 \\
(0.00)\end{array}$ & $\begin{array}{l}0.000 \\
(0.00)\end{array}$ & $\begin{array}{l}-0.000 \\
(0.00)\end{array}$ & $\begin{array}{r}-0.000 \\
(0.00)\end{array}$ \\
\hline _cons & $\begin{array}{r}-0.452 \\
(0.28)\end{array}$ & & $\begin{array}{c}-0.526^{*} \\
(0.29) \\
\end{array}$ & & $\begin{array}{c}-0.944^{* *} \\
(0.46)\end{array}$ & \\
\hline$N$ & 4,914 & 4,914 & 4,419 & 4,419 & 2,268 & 2,268 \\
\hline
\end{tabular}


Table 9: Probit regressions - rural households only (coefficients and average marginal effects)

\begin{tabular}{|c|c|c|c|c|c|c|}
\hline & $\begin{array}{c}\text { (1) } \\
\text { Ethiopia }\end{array}$ & $\begin{array}{c}(2) \\
\mathrm{AME}\end{array}$ & $\begin{array}{c}(3) \\
\text { Malawi }\end{array}$ & $\begin{array}{c}(4) \\
\mathrm{AME}\end{array}$ & $\begin{array}{c}(5) \\
\text { Niger }\end{array}$ & $\begin{array}{c}(6) \\
\text { AME }\end{array}$ \\
\hline Female & $\begin{array}{c}-0.078 \\
(0.12)\end{array}$ & $\begin{array}{c}-0.022 \\
(0.03)\end{array}$ & $\begin{array}{r}-0.017 \\
(0.07)\end{array}$ & $\begin{array}{c}-0.004 \\
(0.02)\end{array}$ & $\begin{array}{c}-0.226 \\
(0.18)\end{array}$ & $\begin{array}{c}-0.084 \\
(0.07)\end{array}$ \\
\hline Age & $\begin{array}{r}-0.012 \\
(0.01)\end{array}$ & $\begin{array}{c}-0.002^{* * *} \\
(0.00)\end{array}$ & $\begin{array}{l}0.002 \\
(0.01)\end{array}$ & $\begin{array}{c}-0.001^{* * *} \\
(0.00)\end{array}$ & $\begin{array}{c}0.032^{* *} \\
(0.01)\end{array}$ & $\begin{array}{l}0.001 \\
(0.00)\end{array}$ \\
\hline Age2 & $\begin{array}{l}0.000 \\
(0.00)\end{array}$ & & $\begin{array}{c}-0.000 \\
(0.00)\end{array}$ & & $\begin{array}{c}-0.000^{* *} \\
(0.00)\end{array}$ & \\
\hline Married & $\begin{array}{c}-0.200 \\
(0.13)\end{array}$ & $\begin{array}{c}-0.060 \\
(0.04)\end{array}$ & $\begin{array}{l}0.107 \\
(0.07)\end{array}$ & $\begin{array}{l}0.025 \\
(0.02)\end{array}$ & $\begin{array}{r}-0.131 \\
(0.18)\end{array}$ & $\begin{array}{r}-0.047 \\
(0.06)\end{array}$ \\
\hline Read \& Write & $\begin{array}{l}0.125 \\
(0.08)\end{array}$ & $\begin{array}{l}0.036 \\
(0.02)\end{array}$ & $\begin{array}{c}0.174^{* * * *} \\
(0.04)\end{array}$ & $\begin{array}{c}0.041^{* * *} \\
(0.01)\end{array}$ & $\begin{array}{l}0.093 \\
(0.09)\end{array}$ & $\begin{array}{l}0.033 \\
(0.03)\end{array}$ \\
\hline HH Size & $\begin{array}{r}-0.076 \\
(0.07)\end{array}$ & $\begin{array}{l}0.001 \\
(0.01)\end{array}$ & $\begin{array}{c}0.061^{*} \\
(0.03)\end{array}$ & $\begin{array}{c}0.010^{* * *} \\
(0.00)\end{array}$ & $\begin{array}{r}-0.059 \\
(0.05)\end{array}$ & $\begin{array}{r}-0.002 \\
(0.01)\end{array}$ \\
\hline HH Size2 & $\begin{array}{l}0.008 \\
(0.01)\end{array}$ & & $\begin{array}{r}-0.002 \\
(0.00)\end{array}$ & & $\begin{array}{l}0.004 \\
(0.00)\end{array}$ & \\
\hline Share of Adults & $\begin{array}{c}-0.433^{* *} \\
(0.21)\end{array}$ & $\begin{array}{c}-0.125^{* *} \\
(0.06)\end{array}$ & $\begin{array}{r}-0.021 \\
(0.11)\end{array}$ & $\begin{array}{c}-0.005 \\
(0.03)\end{array}$ & $\begin{array}{c}-0.388^{*} \\
(0.20)\end{array}$ & $\begin{array}{c}-0.140^{*} \\
(0.07)\end{array}$ \\
\hline Rooms & $\begin{array}{c}0.117^{* * *} \\
(0.04)\end{array}$ & $\begin{array}{c}0.034^{* * *} \\
(0.01)\end{array}$ & $\begin{array}{l}0.026 \\
(0.02)\end{array}$ & $\begin{array}{l}0.006 \\
(0.00)\end{array}$ & $\begin{array}{l}0.013 \\
(0.04)\end{array}$ & $\begin{array}{l}0.005 \\
(0.01)\end{array}$ \\
\hline Credit & $\begin{array}{c}0.295^{* * *} \\
(0.07)\end{array}$ & $\begin{array}{c}0.089^{* * *} \\
(0.02)\end{array}$ & $\begin{array}{c}0.268 * * * \\
(0.05)\end{array}$ & $\begin{array}{c}0.071^{* * *} \\
(0.01)\end{array}$ & & \\
\hline Food Shortage & $\begin{array}{l}0.107 \\
(0.09)\end{array}$ & $\begin{array}{l}0.031 \\
(0.03)\end{array}$ & $\begin{array}{c}-0.136^{* * *} \\
(0.04)\end{array}$ & $\begin{array}{c}-0.033^{* * *} \\
(0.01)\end{array}$ & $\begin{array}{c}-0.256^{* * *} \\
(0.07)\end{array}$ & $\begin{array}{c}-0.094^{* * *} \\
(0.03)\end{array}$ \\
\hline Shock (idiosyn.) & $\begin{array}{l}0.120 \\
(0.08)\end{array}$ & $\begin{array}{l}0.036 \\
(0.03)\end{array}$ & $\begin{array}{c}0.241^{* * *} \\
\quad(0.05)\end{array}$ & $\begin{array}{c}0.062^{* * *} \\
(0.01)\end{array}$ & $\begin{array}{l}0.054 \\
(0.10)\end{array}$ & $\begin{array}{l}0.020 \\
(0.04)\end{array}$ \\
\hline Shock (geogr.) & $\begin{array}{c}-0.143 \\
(0.12)\end{array}$ & $\begin{array}{c}-0.040 \\
(0.03)\end{array}$ & $\begin{array}{c}0.086^{* *} \\
(0.04)\end{array}$ & $\begin{array}{c}0.021^{* *} \\
(0.01)\end{array}$ & $\begin{array}{r}-0.048 \\
(0.08)\end{array}$ & $\begin{array}{r}-0.017 \\
(0.03)\end{array}$ \\
\hline Shock (institut.) & $\begin{array}{l}0.045 \\
(0.10)\end{array}$ & $\begin{array}{l}0.013 \\
(0.03)\end{array}$ & $\begin{array}{l}0.030 \\
(0.04)\end{array}$ & $\begin{array}{c}0.007 \\
(0.01)\end{array}$ & $\begin{array}{l}0.072 \\
(0.09)\end{array}$ & $\begin{array}{l}0.026 \\
(0.03)\end{array}$ \\
\hline Shock (other) & $\begin{array}{l}0.378^{*} \\
(0.21)\end{array}$ & $\begin{array}{l}0.122 \\
(0.08)\end{array}$ & $\begin{array}{l}0.072 \\
(0.15)\end{array}$ & $\begin{array}{l}0.018 \\
(0.04)\end{array}$ & $\begin{array}{c}0.256^{* * *} \\
(0.09)\end{array}$ & $\begin{array}{c}0.090^{* * *} \\
(0.03)\end{array}$ \\
\hline Dist to Road & $\begin{array}{l}0.001 \\
(0.01)\end{array}$ & $\begin{array}{l}0.000 \\
(0.00)\end{array}$ & $\begin{array}{r}-0.001 \\
(0.01)\end{array}$ & $\begin{array}{r}-0.000 \\
(0.00)\end{array}$ & $\begin{array}{c}-0.008 \\
(0.01)\end{array}$ & $\begin{array}{c}-0.003 \\
(0.00)\end{array}$ \\
\hline Dist to Road2 & $\begin{array}{l}0.000 \\
(0.00)\end{array}$ & & $\begin{array}{r}-0.000 \\
(0.00)\end{array}$ & & $\begin{array}{l}0.000 \\
(0.00)\end{array}$ & \\
\hline Dist to Popcenter & $\begin{array}{r}-0.001 \\
(0.00)\end{array}$ & $\begin{array}{c}-0.000 \\
(0.00)\end{array}$ & $\begin{array}{c}-0.011^{* * *} \\
(0.00)\end{array}$ & $\begin{array}{c}-0.001^{* * *} \\
(0.00)\end{array}$ & $\begin{array}{r}-0.005 \\
(0.00)\end{array}$ & $\begin{array}{r}-0.001 \\
(0.00)\end{array}$ \\
\hline Dist to Popcenter2 & $\begin{array}{r}-0.000 \\
(0.00)\end{array}$ & & $\begin{array}{c}0.000^{* * *} \\
(0.00)\end{array}$ & & $\begin{array}{l}0.000 \\
(0.00)\end{array}$ & \\
\hline Precipitation & $\begin{array}{l}0.000 \\
(0.00)\end{array}$ & $\begin{array}{l}0.000 \\
(0.00)\end{array}$ & $\begin{array}{c}-0.000 \\
(0.00)\end{array}$ & $\begin{array}{c}-0.000 \\
(0.00)\end{array}$ & $\begin{array}{l}0.001 \\
(0.00)\end{array}$ & $\begin{array}{l}0.000 \\
(0.00)\end{array}$ \\
\hline _cons & $\begin{array}{r}-0.219 \\
(0.45)\end{array}$ & & $\begin{array}{c}-1.053^{* * *} \\
(0.23)\end{array}$ & & $\begin{array}{l}0.004 \\
(0.56)\end{array}$ & \\
\hline$N$ & 3,320 & 3,320 & 10,017 & 10,017 & 2,430 & 2,430 \\
\hline
\end{tabular}




\begin{tabular}{|c|c|c|c|c|c|c|}
\hline & $\begin{array}{c}(7) \\
\text { Nigeria }\end{array}$ & $\begin{array}{c}(8) \\
\mathrm{AME}\end{array}$ & $\begin{array}{c}(9) \\
\text { Tanzania }\end{array}$ & $\begin{array}{c}(10) \\
\text { AME }\end{array}$ & $\begin{array}{c}(11) \\
\text { Uganda }\end{array}$ & $\begin{array}{c}(12) \\
\text { AME }\end{array}$ \\
\hline Female & $\begin{array}{c}0.319^{* *} \\
(0.13)\end{array}$ & $\begin{array}{c}0.117^{* *} \\
(0.05)\end{array}$ & $\begin{array}{l}0.124 \\
(0.09)\end{array}$ & $\begin{array}{c}0.046 \\
(0.03)\end{array}$ & $\begin{array}{l}0.005 \\
(0.10)\end{array}$ & $\begin{array}{l}0.002 \\
(0.04)\end{array}$ \\
\hline Age & $\begin{array}{l}0.018 \\
(0.01)\end{array}$ & $\begin{array}{r}-0.001 \\
(0.00)\end{array}$ & $\begin{array}{l}0.000 \\
(0.01)\end{array}$ & $\begin{array}{c}-0.004^{* * *} \\
(0.00)\end{array}$ & $\begin{array}{c}0.037^{* *} \\
(0.02)\end{array}$ & $\begin{array}{c}-0.004^{* * *} \\
(0.00)\end{array}$ \\
\hline Age2 & $\begin{array}{c}-0.000^{* *} \\
(0.00)\end{array}$ & & $\begin{array}{r}-0.000 \\
(0.00)\end{array}$ & & $\begin{array}{c}-0.001^{* * *} \\
(0.00)\end{array}$ & \\
\hline Married & $\begin{array}{c}0.309^{* *} \\
(0.12)\end{array}$ & $\begin{array}{c}0.118^{* * *} \\
(0.05)\end{array}$ & $\begin{array}{c}-0.124^{*} \\
(0.07)\end{array}$ & $\begin{array}{c}-0.046^{*} \\
(0.03)\end{array}$ & $\begin{array}{l}0.155 \\
(0.12)\end{array}$ & $\begin{array}{l}0.056 \\
(0.04)\end{array}$ \\
\hline Read \& Write & $\begin{array}{c}0.329^{* * *} \\
(0.07)\end{array}$ & $\begin{array}{c}0.126^{* * *} \\
(0.02)\end{array}$ & $\begin{array}{c}0.201^{* *} \\
(0.08)\end{array}$ & $\begin{array}{c}0.073^{* *} \\
(0.03)\end{array}$ & $\begin{array}{l}0.007 \\
(0.08)\end{array}$ & $\begin{array}{l}0.002 \\
(0.03)\end{array}$ \\
\hline HH Size & $\begin{array}{c}0.083^{* * *} \\
(0.03)\end{array}$ & $\begin{array}{c}0.025^{* * *} \\
(0.01)\end{array}$ & $\begin{array}{c}0.059^{* * *} \\
(0.02)\end{array}$ & $\begin{array}{c}0.018^{* * *} \\
(0.01)\end{array}$ & $\begin{array}{c}0.118^{* * *} \\
(0.03)\end{array}$ & $\begin{array}{c}0.022^{* * *} \\
(0.01)\end{array}$ \\
\hline HH Size2 & $\begin{array}{r}-0.001 \\
(0.00)\end{array}$ & & $\begin{array}{r}-0.001 \\
(0.00)\end{array}$ & & $\begin{array}{c}-0.004^{* * *} \\
(0.00)\end{array}$ & \\
\hline Share of Adults & $\begin{array}{l}0.228 \\
(0.14)\end{array}$ & $\begin{array}{l}0.086 \\
(0.05)\end{array}$ & $\begin{array}{l}0.287 \\
(0.17)\end{array}$ & $\begin{array}{c}0.105^{*} \\
(0.06)\end{array}$ & $\begin{array}{c}0.567^{* * *} \\
(0.19)\end{array}$ & $\begin{array}{c}0.205^{* * *} \\
(0.07)\end{array}$ \\
\hline Rooms & & & $\begin{array}{c}0.079^{* * *} \\
(0.02)\end{array}$ & $\begin{array}{c}0.029^{* * *} \\
(0.01)\end{array}$ & $\begin{array}{l}0.017 \\
(0.03)\end{array}$ & $\begin{array}{l}0.006 \\
(0.01)\end{array}$ \\
\hline Credit & & & $\begin{array}{c}0.089 \\
(0.12)\end{array}$ & $\begin{array}{l}0.033 \\
(0.05)\end{array}$ & & \\
\hline Food Shortage & $\begin{array}{l}0.034 \\
(0.06)\end{array}$ & $\begin{array}{l}0.013 \\
(0.02)\end{array}$ & $\begin{array}{r}-0.012 \\
(0.08)\end{array}$ & $\begin{array}{c}-0.005 \\
(0.03)\end{array}$ & $\begin{array}{c}0.192^{*} \\
(0.10)\end{array}$ & $\begin{array}{c}0.070^{* *} \\
(0.04)\end{array}$ \\
\hline Shock (idiosyn.) & $\begin{array}{c}-0.106 \\
(0.07)\end{array}$ & $\begin{array}{r}-0.040 \\
(0.03)\end{array}$ & $\begin{array}{l}0.059 \\
(0.10)\end{array}$ & $\begin{array}{c}0.022 \\
(0.04)\end{array}$ & $\begin{array}{c}0.083 \\
(0.09)\end{array}$ & $\begin{array}{l}0.030 \\
(0.03)\end{array}$ \\
\hline Shock (geogr.) & $\begin{array}{c}-0.138 \\
(0.09)\end{array}$ & $\begin{array}{r}-0.052 \\
(0.03)\end{array}$ & $\begin{array}{l}0.021 \\
(0.09)\end{array}$ & $\begin{array}{l}0.008 \\
(0.03)\end{array}$ & $\begin{array}{l}0.082 \\
(0.09)\end{array}$ & $\begin{array}{l}0.030 \\
(0.03)\end{array}$ \\
\hline Shock (institut.) & $\begin{array}{l}0.009 \\
(0.09)\end{array}$ & $\begin{array}{c}0.003 \\
(0.03)\end{array}$ & $\begin{array}{r}-0.055 \\
(0.09)\end{array}$ & $\begin{array}{c}-0.020 \\
(0.03)\end{array}$ & $\begin{array}{r}-0.083 \\
(0.16)\end{array}$ & $\begin{array}{r}-0.030 \\
(0.06)\end{array}$ \\
\hline Shock (other) & $\begin{array}{c}0.041 \\
(0.25)\end{array}$ & $\begin{array}{c}0.016 \\
(0.09)\end{array}$ & $\begin{array}{r}-0.181 \\
(0.41)\end{array}$ & $\begin{array}{c}-0.064 \\
(0.14)\end{array}$ & $\begin{array}{l}0.226 \\
(0.23)\end{array}$ & $\begin{array}{c}0.083 \\
(0.09)\end{array}$ \\
\hline Dist to Road & $\begin{array}{c}-0.009^{*} \\
(0.00)\end{array}$ & $\begin{array}{c}-0.002^{* *} \\
(0.00)\end{array}$ & $\begin{array}{c}-0.003 \\
(0.00)\end{array}$ & $\begin{array}{r}-0.000 \\
(0.00)\end{array}$ & $\begin{array}{c}-0.038^{* *} \\
(0.02)\end{array}$ & $\begin{array}{c}-0.004 \\
(0.00)\end{array}$ \\
\hline Dist to Road2 & $\begin{array}{l}0.000 \\
(0.00)\end{array}$ & & $\begin{array}{l}0.000 \\
(0.00)\end{array}$ & & $\begin{array}{c}0.002^{* * *} \\
(0.00)\end{array}$ & \\
\hline Dist to Popcenter & $\begin{array}{c}-0.004 \\
(0.01)\end{array}$ & $\begin{array}{r}-0.001 \\
(0.00)\end{array}$ & $\begin{array}{r}-0.002 \\
(0.00)\end{array}$ & $\begin{array}{r}-0.001 \\
(0.00)\end{array}$ & $\begin{array}{c}-0.022^{* *} \\
(0.01)\end{array}$ & $\begin{array}{c}-0.003^{*} \\
(0.00)\end{array}$ \\
\hline Dist to Popcenter2 & $\begin{array}{l}0.000 \\
(0.00)\end{array}$ & & $\begin{array}{l}0.000 \\
(0.00)\end{array}$ & & $\begin{array}{c}0.000^{* *} \\
(0.00)\end{array}$ & \\
\hline Precipitation & $\begin{array}{r}-0.000 \\
(0.00)\end{array}$ & $\begin{array}{r}-0.000 \\
(0.00)\end{array}$ & $\begin{array}{r}-0.000 \\
(0.00)\end{array}$ & $\begin{array}{c}-0.000 \\
(0.00)\end{array}$ & $\begin{array}{r}-0.000 \\
(0.00)\end{array}$ & $\begin{array}{r}-0.000 \\
(0.00)\end{array}$ \\
\hline _cons & $\begin{array}{c}-0.990^{* * *} \\
(0.34)\end{array}$ & & $\begin{array}{c}-0.676^{* *} \\
(0.34)\end{array}$ & & $\begin{array}{c}-1.231^{* *} \\
(0.52)\end{array}$ & \\
\hline$N$ & 3,324 & 3,324 & 2,956 & 2,956 & 1,789 & 1,789 \\
\hline
\end{tabular}


Table 10: Probit regressions - urban households only (coefficients and average marginal effects)

\begin{tabular}{|c|c|c|c|c|c|c|}
\hline & $\begin{array}{c}(1) \\
\text { Ethiopia }\end{array}$ & $\begin{array}{c}(2) \\
\mathrm{AME}\end{array}$ & $\begin{array}{c}(3) \\
\text { Malawi }\end{array}$ & $\begin{array}{c}(4) \\
\mathrm{AME}\end{array}$ & $\begin{array}{c}(5) \\
\text { Niger }\end{array}$ & $\begin{array}{c}(6) \\
\mathrm{AME}\end{array}$ \\
\hline Female & $\begin{array}{l}0.433 \\
(0.26)\end{array}$ & $\begin{array}{c}0.147^{*} \\
(0.08)\end{array}$ & $\begin{array}{l}0.056 \\
(0.16)\end{array}$ & $\begin{array}{l}0.020 \\
(0.06)\end{array}$ & $\begin{array}{l}0.003 \\
(0.17)\end{array}$ & $\begin{array}{l}0.001 \\
(0.06)\end{array}$ \\
\hline Age & $\begin{array}{c}-0.004 \\
(0.02)\end{array}$ & $\begin{array}{l}0.001 \\
(0.00)\end{array}$ & $\begin{array}{l}0.021 \\
(0.01)\end{array}$ & $\begin{array}{r}-0.002 \\
(0.00)\end{array}$ & $\begin{array}{c}-0.015 \\
(0.02)\end{array}$ & $\begin{array}{c}-0.002^{*} \\
(0.00)\end{array}$ \\
\hline Age2 & $\begin{array}{l}0.000 \\
(0.00)\end{array}$ & & $\begin{array}{c}-0.000^{* *} \\
(0.00)\end{array}$ & & $\begin{array}{l}0.000 \\
(0.00)\end{array}$ & \\
\hline Married & $\begin{array}{r}-0.057 \\
(0.20)\end{array}$ & $\begin{array}{c}-0.020 \\
(0.07)\end{array}$ & $\begin{array}{l}0.127 \\
(0.13)\end{array}$ & $\begin{array}{l}0.044 \\
(0.04)\end{array}$ & $\begin{array}{l}0.230 \\
(0.16)\end{array}$ & $\begin{array}{l}0.079 \\
(0.06)\end{array}$ \\
\hline Read \& Write & $\begin{array}{r}-0.175 \\
(0.22)\end{array}$ & $\begin{array}{r}-0.061 \\
(0.08)\end{array}$ & $\begin{array}{r}-0.070 \\
(0.15)\end{array}$ & $\begin{array}{c}-0.025 \\
(0.05)\end{array}$ & $\begin{array}{c}-0.459^{* * *} \\
(0.10)\end{array}$ & $\begin{array}{c}-0.155^{* * *} \\
(0.03)\end{array}$ \\
\hline HH Size & $\begin{array}{c}0.304^{* *} \\
(0.14)\end{array}$ & $\begin{array}{c}0.078^{* * *} \\
(0.02)\end{array}$ & $\begin{array}{c}0.137^{*} \\
(0.07)\end{array}$ & $\begin{array}{c}0.035^{* * *} \\
(0.01)\end{array}$ & $\begin{array}{l}0.058 \\
(0.04)\end{array}$ & $\begin{array}{c}0.020^{* * *} \\
(0.01)\end{array}$ \\
\hline HH Size2 & $\begin{array}{r}-0.011 \\
(0.01)\end{array}$ & & $\begin{array}{c}-0.004 \\
(0.01)\end{array}$ & & $\begin{array}{l}0.000 \\
(0.00)\end{array}$ & \\
\hline Share of Adults & $\begin{array}{c}0.593^{*} \\
(0.34)\end{array}$ & $\begin{array}{c}0.205^{*} \\
(0.12)\end{array}$ & $\begin{array}{l}0.189 \\
(0.24)\end{array}$ & $\begin{array}{l}0.066 \\
(0.08)\end{array}$ & $\begin{array}{c}-0.239 \\
(0.25)\end{array}$ & $\begin{array}{c}-0.080 \\
(0.08)\end{array}$ \\
\hline Rooms & $\begin{array}{l}0.012 \\
(0.07)\end{array}$ & $\begin{array}{l}0.004 \\
(0.02)\end{array}$ & $\begin{array}{l}0.028 \\
(0.03)\end{array}$ & $\begin{array}{l}0.010 \\
(0.01)\end{array}$ & $\begin{array}{c}-0.029 \\
(0.03)\end{array}$ & $\begin{array}{c}-0.010 \\
(0.01)\end{array}$ \\
\hline Credit & $\begin{array}{c}0.670^{* * *} \\
(0.21)\end{array}$ & $\begin{array}{c}0.221^{* * *} \\
(0.06)\end{array}$ & $\begin{array}{c}-0.003 \\
(0.14)\end{array}$ & $\begin{array}{r}-0.001 \\
(0.05)\end{array}$ & & \\
\hline Food Shortage & $\begin{array}{c}-0.122 \\
(0.24)\end{array}$ & $\begin{array}{c}-0.043 \\
(0.09)\end{array}$ & $\begin{array}{c}-0.152^{*} \\
(0.09)\end{array}$ & $\begin{array}{c}-0.053^{*} \\
(0.03)\end{array}$ & $\begin{array}{c}-0.030 \\
(0.14)\end{array}$ & $\begin{array}{r}-0.010 \\
(0.05)\end{array}$ \\
\hline Shock (idiosyn.) & $\begin{array}{c}-0.034 \\
(0.24)\end{array}$ & $\begin{array}{r}-0.012 \\
(0.08)\end{array}$ & $\begin{array}{c}0.425^{* * *} \\
(0.08)\end{array}$ & $\begin{array}{c}0.156^{* * *} \\
(0.03)\end{array}$ & $\begin{array}{l}0.031 \\
(0.11)\end{array}$ & $\begin{array}{l}0.010 \\
(0.04)\end{array}$ \\
\hline Shock (geogr.) & $\begin{array}{r}-0.542 \\
(0.33)\end{array}$ & $\begin{array}{c}-0.190^{*} \\
(0.11)\end{array}$ & $\begin{array}{c}-0.000 \\
(0.13)\end{array}$ & $\begin{array}{c}-0.000 \\
(0.05)\end{array}$ & $\begin{array}{r}-0.166 \\
(0.16)\end{array}$ & $\begin{array}{r}-0.057 \\
(0.06)\end{array}$ \\
\hline Shock (institut.) & $\begin{array}{c}0.157 \\
(0.12)\end{array}$ & $\begin{array}{c}0.054 \\
(0.04)\end{array}$ & $\begin{array}{c}-0.211^{* *} \\
(0.11)\end{array}$ & $\begin{array}{c}-0.073^{* *} \\
(0.04)\end{array}$ & $\begin{array}{c}0.182^{* *} \\
(0.09)\end{array}$ & $\begin{array}{c}0.060^{* *} \\
(0.03)\end{array}$ \\
\hline Shock (other) & $\begin{array}{c}-0.743 \\
(0.62)\end{array}$ & $\begin{array}{c}-0.255 \\
(0.20)\end{array}$ & $\begin{array}{r}-0.181 \\
(0.24)\end{array}$ & $\begin{array}{r}-0.061 \\
(0.08)\end{array}$ & $\begin{array}{c}-0.029 \\
(0.13)\end{array}$ & $\begin{array}{c}-0.010 \\
(0.04)\end{array}$ \\
\hline Dist to Road & $\begin{array}{l}0.005 \\
(0.01)\end{array}$ & $\begin{array}{c}0.000 \\
(0.00)\end{array}$ & $\begin{array}{c}-0.006 \\
(0.04)\end{array}$ & $\begin{array}{r}-0.001 \\
(0.01)\end{array}$ & $\begin{array}{c}0.011 \\
(0.10)\end{array}$ & $\begin{array}{r}-0.012 \\
(0.02)\end{array}$ \\
\hline Dist to Road2 & $\begin{array}{c}-0.000 \\
(0.00)\end{array}$ & & $\begin{array}{l}0.000 \\
(0.00)\end{array}$ & & $\begin{array}{c}-0.024^{*} \\
(0.01)\end{array}$ & \\
\hline Dist to Popcenter & $\begin{array}{l}0.005 \\
(0.01)\end{array}$ & $\begin{array}{c}0.001 \\
(0.00)\end{array}$ & $\begin{array}{r}-0.006 \\
(0.01)\end{array}$ & $\begin{array}{r}-0.001 \\
(0.00)\end{array}$ & $\begin{array}{r}-0.001 \\
(0.01)\end{array}$ & $\begin{array}{r}-0.000 \\
(0.00)\end{array}$ \\
\hline Dist to Popcenter2 & $\begin{array}{c}-0.000 \\
(0.00)\end{array}$ & & $\begin{array}{l}0.000 \\
(0.00)\end{array}$ & & $\begin{array}{r}-0.000 \\
(0.00)\end{array}$ & \\
\hline Precipitation & $\begin{array}{c}0.000 \\
(0.00)\end{array}$ & $\begin{array}{c}0.000 \\
(0.00)\end{array}$ & $\begin{array}{c}-0.001^{*} \\
(0.00)\end{array}$ & $\begin{array}{c}-0.000^{*} \\
(0.00)\end{array}$ & $\begin{array}{r}-0.001 \\
(0.00)\end{array}$ & $\begin{array}{c}-0.000 \\
(0.00)\end{array}$ \\
\hline _cons & $\begin{array}{c}-1.695^{* *} \\
(0.70)\end{array}$ & & $\begin{array}{c}-0.796 \\
(0.58)\end{array}$ & & $\begin{array}{c}1.122^{* *} \\
(0.50)\end{array}$ & \\
\hline$N$ & 477 & 477 & 2,229 & 2,229 & 1,535 & 1,535 \\
\hline
\end{tabular}




\begin{tabular}{|c|c|c|c|c|c|c|}
\hline & $\begin{array}{c}(7) \\
\text { Nigeria } \\
\end{array}$ & $\begin{array}{c}(8) \\
\text { AME } \\
\end{array}$ & $\begin{array}{c}(9) \\
\text { Tanzania } \\
\end{array}$ & $\begin{array}{c}(10) \\
\text { AME }\end{array}$ & $\begin{array}{c}\text { (11) } \\
\text { Uganda }\end{array}$ & $\begin{array}{c}(12) \\
\text { AME }\end{array}$ \\
\hline Female & $\begin{array}{l}0.113 \\
(0.16)\end{array}$ & $\begin{array}{l}0.035 \\
(0.05)\end{array}$ & $\begin{array}{l}0.100 \\
(0.11)\end{array}$ & $\begin{array}{l}0.036 \\
(0.04)\end{array}$ & $\begin{array}{l}0.094 \\
(0.19)\end{array}$ & $\begin{array}{l}0.032 \\
(0.06)\end{array}$ \\
\hline Age & $\begin{array}{c}0.027^{*} \\
(0.02)\end{array}$ & $\begin{array}{c}-0.001 \\
(0.00)\end{array}$ & $\begin{array}{l}0.009 \\
(0.02)\end{array}$ & $\begin{array}{c}-0.001 \\
(0.00)\end{array}$ & $\begin{array}{l}0.033 \\
(0.03)\end{array}$ & $\begin{array}{l}0.002 \\
(0.00)\end{array}$ \\
\hline Age2 & $\begin{array}{c}-0.000^{* *} \\
(0.00)\end{array}$ & & $\begin{array}{l}-0.000 \\
(0.00)\end{array}$ & & $\begin{array}{l}-0.000 \\
(0.00)\end{array}$ & \\
\hline Married & $\begin{array}{l}0.182 \\
(0.14)\end{array}$ & $\begin{array}{l}0.060 \\
(0.05)\end{array}$ & $\begin{array}{l}0.080 \\
(0.12)\end{array}$ & $\begin{array}{l}0.029 \\
(0.04)\end{array}$ & $\begin{array}{l}0.122 \\
(0.20)\end{array}$ & $\begin{array}{l}0.042 \\
(0.07)\end{array}$ \\
\hline Read \& Write & $\begin{array}{c}-0.236^{* *} \\
(0.10)\end{array}$ & $\begin{array}{c}-0.073^{* *} \\
(0.03)\end{array}$ & $\begin{array}{l}0.255 \\
(0.18)\end{array}$ & $\begin{array}{l}0.095 \\
(0.07)\end{array}$ & $\begin{array}{l}0.004 \\
(0.20)\end{array}$ & $\begin{array}{l}0.001 \\
(0.07)\end{array}$ \\
\hline HH Size & $\begin{array}{c}0.204^{* * *} \\
(0.05)\end{array}$ & $\begin{array}{c}0.030^{* * *} \\
(0.01)\end{array}$ & $\begin{array}{c}0.232^{* * * *} \\
(0.06)\end{array}$ & $\begin{array}{c}0.050^{* * *} \\
(0.01)\end{array}$ & $\begin{array}{c}0.187^{* * *} \\
(0.05)\end{array}$ & $\begin{array}{c}0.029^{* * *} \\
(0.01)\end{array}$ \\
\hline HH Size2 & $\begin{array}{c}-0.012^{* * *} \\
(0.00)\end{array}$ & & $\begin{array}{c}-0.011^{* * *} \\
(0.00)\end{array}$ & & $\begin{array}{c}-0.009^{* * *} \\
(0.00)\end{array}$ & \\
\hline Share of Adults & $\begin{array}{l}-0.280 \\
(0.27)\end{array}$ & $\begin{array}{l}-0.090 \\
(0.09)\end{array}$ & $\begin{array}{l}0.235 \\
(0.27)\end{array}$ & $\begin{array}{l}0.085 \\
(0.10)\end{array}$ & $\begin{array}{l}-0.522 \\
(0.40)\end{array}$ & $\begin{array}{l}-0.177 \\
(0.14)\end{array}$ \\
\hline Rooms & & & $\begin{array}{l}-0.001 \\
(0.03)\end{array}$ & $\begin{array}{l}-0.001 \\
(0.01)\end{array}$ & $\begin{array}{l}-0.022 \\
(0.05)\end{array}$ & $\begin{array}{l}-0.007 \\
(0.02)\end{array}$ \\
\hline Credit & & & $\begin{array}{l}0.201 \\
(0.14)\end{array}$ & $\begin{array}{l}0.071 \\
(0.05)\end{array}$ & & \\
\hline Food Shortage & $\begin{array}{l}0.092 \\
(0.11)\end{array}$ & $\begin{array}{l}0.030 \\
(0.03)\end{array}$ & $\begin{array}{l}0.173 \\
(0.12)\end{array}$ & $\begin{array}{l}0.061 \\
(0.04)\end{array}$ & $\begin{array}{r}-0.135 \\
(0.22)\end{array}$ & $\begin{array}{l}-0.047 \\
(0.08)\end{array}$ \\
\hline Shock (idiosyn.) & $\begin{array}{l}-0.003 \\
(0.10)\end{array}$ & $\begin{array}{l}-0.001 \\
(0.03)\end{array}$ & $\begin{array}{l}-0.098 \\
(0.10)\end{array}$ & $\begin{array}{l}-0.036 \\
(0.04)\end{array}$ & $\begin{array}{c}-0.552^{* * *} \\
(0.19)\end{array}$ & $\begin{array}{c}-0.197^{* * *} \\
(0.07)\end{array}$ \\
\hline Shock (geogr.) & $\begin{array}{c}-0.246 \\
(0.19)\end{array}$ & $\begin{array}{c}-0.083 \\
(0.07)\end{array}$ & $\begin{array}{c}-0.091 \\
(0.13)\end{array}$ & $\begin{array}{c}-0.033 \\
(0.05)\end{array}$ & $\begin{array}{l}0.220 \\
(0.24)\end{array}$ & $\begin{array}{l}0.073 \\
(0.08)\end{array}$ \\
\hline Shock (institut.) & $\begin{array}{l}-0.096 \\
(0.13)\end{array}$ & $\begin{array}{l}-0.031 \\
(0.04)\end{array}$ & $\begin{array}{l}0.105 \\
(0.10)\end{array}$ & $\begin{array}{l}0.038 \\
(0.04)\end{array}$ & $\begin{array}{l}0.395 \\
(0.31)\end{array}$ & $\begin{array}{l}0.126 \\
(0.09)\end{array}$ \\
\hline Shock (other) & $\begin{array}{l}0.014 \\
(0.27)\end{array}$ & $\begin{array}{l}0.004 \\
(0.09)\end{array}$ & $\begin{array}{c}0.855^{* *} \\
(0.35)\end{array}$ & $\begin{array}{c}0.253^{* * *} \\
(0.07)\end{array}$ & $\begin{array}{c}-1.056^{* *} \\
(0.42)\end{array}$ & $\begin{array}{c}-0.363^{* * *} \\
(0.12)\end{array}$ \\
\hline Dist to Road & $\begin{array}{l}-0.007 \\
(0.01)\end{array}$ & $\begin{array}{l}-0.002 \\
(0.00)\end{array}$ & $\begin{array}{l}-0.011 \\
(0.01)\end{array}$ & $\begin{array}{l}-0.004 \\
(0.00)\end{array}$ & $\begin{array}{c}-0.099^{* *} \\
(0.05)\end{array}$ & $\begin{array}{c}-0.028^{* *} \\
(0.01)\end{array}$ \\
\hline Dist to Road2 & $\begin{array}{l}-0.000 \\
(0.00)\end{array}$ & & $\begin{array}{l}0.000 \\
(0.00)\end{array}$ & & $\begin{array}{l}0.003^{*} \\
(0.00)\end{array}$ & \\
\hline Dist to Popcenter & $\begin{array}{l}0.011 \\
(0.01)\end{array}$ & $\begin{array}{l}0.003 \\
(0.00)\end{array}$ & $\begin{array}{l}0.001 \\
(0.01)\end{array}$ & $\begin{array}{l}0.000 \\
(0.00)\end{array}$ & $\begin{array}{l}0.018 \\
(0.01)\end{array}$ & $\begin{array}{l}0.005 \\
(0.00)\end{array}$ \\
\hline Dist to Popcenter2 & $\begin{array}{l}-0.000 \\
(0.00)\end{array}$ & & $\begin{array}{l}0.000 \\
(0.00)\end{array}$ & & $\begin{array}{l}-0.000 \\
(0.00)\end{array}$ & \\
\hline Precipitation & $\begin{array}{c}-0.000^{*} \\
(0.00)\end{array}$ & $\begin{array}{c}-0.000^{*} \\
(0.00)\end{array}$ & $\begin{array}{l}0.000 \\
(0.00)\end{array}$ & $\begin{array}{l}0.000 \\
(0.00)\end{array}$ & $\begin{array}{l}-0.001 \\
(0.00)\end{array}$ & $\begin{array}{c}-0.000 \\
(0.00)\end{array}$ \\
\hline _cons & $\begin{array}{l}-0.052 \\
(0.50)\end{array}$ & & $\begin{array}{c}-1.294^{* *} \\
(0.51)\end{array}$ & & $\begin{array}{l}0.094 \\
(1.12)\end{array}$ & \\
\hline$N$ & 1,590 & 1,590 & 1,463 & 1,463 & 479 & 479 \\
\hline
\end{tabular}

